Pontifícia Universidade $C_{\text {atólica }}$

Claudio Henrique Sales de Souza

\title{
Oralidade e escrita nas aulas de Matemática:
} proposição de atividades

Dissertação apresentada como requisito parcial para obtenção do grau de Mestre pelo Programa de Pós-graduação em Matemática, do Departamento de Matemática da PUC-Rio.

Orientadora: Prof ${ }^{a}$ Christine Sertã Costa 


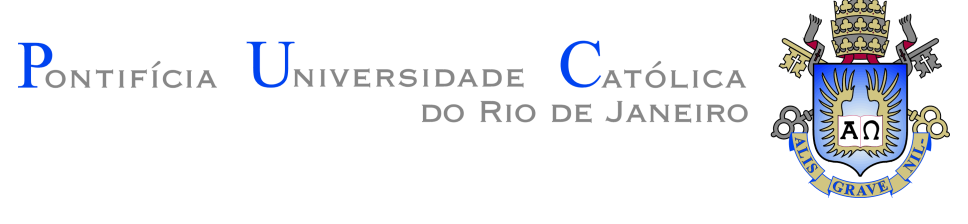

Claudio Henrique Sales de Souza

\title{
Oralidade e escrita nas aulas de Matemática: proposição de atividades
}

Dissertação apresentada como requisito parcial para obtenção do grau de Mestre pelo Programa de Pós-graduação em Matemática da PUC-Rio. Aprovada pela Comissão Examinadora abaixo:

\author{
Prof $^{a}$ Christine Sertã Costa \\ Orientadora \\ Departamento de Matemática - PUC-Rio \\ Profa Liliana Manuela Gaspar Cerveira da Costa \\ NEPEM - CPII \\ Prof Marcos Craizer \\ Departamento de Matemática - PUC-RJ \\ Prof ${ }^{a}$ Renata Martins da Rosa \\ Departamento de Matemática - PUC-RJ
}

Rio de Janeiro, 14 de Setembro de 2021 
Todos os direitos reservados. A reprodução, total ou parcial do trabalho, é proibida sem a autorização da universidade, do autor e do orientador.

\section{Claudio Henrique Sales de Souza}

Licenciado em Matemática pela Universidade Federal do Rio de Janeiro(UFRJ). Especialista em Educação Matemática pelo Colégio Pedro II(CPII). Professor da rede municipal do Rio de Janeiro.

Ficha Catalográfica

Souza, Claudio Henrique Sales de

Oralidade e escrita nas aulas de Matemática: proposição de atividades / Claudio Henrique Sales de Souza; orientadora: Christine Sertã Costa. - 2021.

76 f: il. color. ; $30 \mathrm{~cm}$

Dissertação (mestrado) - Pontifícia Universidade Católica do Rio de Janeiro, Departamento de Matemática, 2021.

Inclui bibliografia

1. Matemática - Teses. 2. Argumentação. 3. Ensino de Matemática. 4. Escrita. 5. Língua Portuguesa. 6. Oralidade. I. Costa, Christine Sertã. II. Pontifícia Universidade Católica do Rio de Janeiro. Departamento de Matemática. III. Título. 


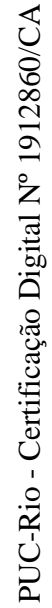

Aos meus pais José Antônio e Maria Maura 


\section{Agradecimentos}

Primeiramente agradeço a Deus pelo dom da vida.

Agradeço aos meus pais, José e Maria, e a minha irmã, Daniele, que sempre me incentivaram em todos os meus projetos.

Agradeço a minha esposa, Agatha, e ao fruto do nosso amor, Olivia, que estiveram comigo durante a jornada do mestrado.

Agradeço a todos os professores e professoras que encontrei na PUC e em toda minha caminhada acadêmica. Com certeza todos têm influência no profissional que me tornei.

Em especial, agradeço a Professora Christine pela parceria na escrita desta dissertação.

Agradeço a todos os colegas que compartilharam essa jornada comigo.

O presente trabalho foi realizado com apoio da Coordenação de Aperfeiçoamento de Pessoal de Nível Superior - Brasil (CAPES) - Código de Financiamento 001. 


\section{Resumo}

Souza, Claudio Henrique Sales de; Costa, Christine Sertã. Oralidade e escrita nas aulas de Matemática: proposição de atividades. Rio de Janeiro, 2021. 76p. Dissertação de Mestrado Departamento de Matemática, Pontifícia Universidade Católica do Rio de Janeiro.

Este trabalho tem como objetivo apresentar uma coleção de atividades voltadas para o desenvolvimento da escrita e da oralidade nas aulas de Matemática para os anos finais do Ensino Fundamental e para o Ensino Médio da escola básica. A fundamentação teórica apresentada promove reflexão acerca da interação entre a Língua Portuguesa e a Matemática, o uso de atividades que estimulem essa interação e objetiva oportunizar o aprimoramento das linguagens escrita e oral no chão da escola. A reflexão teve por base os Parâmetros Curriculares Nacionais, a Base Nacional Comum Curricular e artigos científicos de autores que tratam deste tema. Os conceitos e resultados matemáticos utilizados nas atividades estão definidos ou demonstrados no trabalho e servem como suporte teórico ao que é proposto. A análise dos documentos citados e do conteúdo do referencial teórico aponta que a interação aqui proposta é possível, importante e favorece o desenvolvimento não só das linguagens oral e escrita como também contribui para a apropriação dos conceitos matemáticos trabalhados e para o exercício da autonomia e da criticidade.

\section{Palavras-chave}

Argumentação; Ensino de Matemática; Escrita; Língua Portuguesa; Oralidade. 


\section{Abstract}

Souza, Claudio Henrique Sales de; Costa, Christine Sertã (Advisor). Orality and writing in Mathematics classes: proposition of activities. Rio de Janeiro, 2021. 76p. Dissertação de Mestrado Departamento de Matemática, Pontifícia Universidade Católica do Rio de Janeiro.

This work aims to present a collection of activities aimed at developing writing and speaking skills in Mathematics classes for the final years of elementary school and for high school. The theoretical foundation presented promotes reflection on the interaction between Portuguese Language and Mathematics, the use of activities that encourage this interaction and aims to provide opportunities for the improvement of written and oral languages on the school floor. The reflection was based on the National Curriculum Parameters, the Common National Curriculum Base and scientific articles by authors who deal with this topic. The concepts and mathematical results used in the activities are defined or demonstrated in the work and serve as theoretical support for what is proposed. The analysis of the cited documents and the content of the theoretical framework points out that the interaction proposed here is possible, important and favors the development not only of oral and written languages, but also contributes to the appropriation of the mathematical concepts worked on and to the exercise of autonomy and criticality.

\section{Keywords}

Argumentation; Math Teaching; Writing; Portuguese Language; Orality. 


\section{Sumário}

1 Introdução 13

2 Fundamentação teórica $\quad 15$

2.1 A aula de Matemática e a formação de cidadão críticos $\quad 16$

$\begin{array}{lll}2.2 \text { A oralidade } & 18\end{array}$

$\begin{array}{lll}2.3 \text { A escrita } & 21\end{array}$

3 Atividades Propostas 24

3.1 Atividade 1: Decomposição em fatores primos 24

3.2 Atividade 2: Perpendicularidade entre o raio e a reta tangente a um círculo 28

3.3 Atividade 3: Criando um problema a partir de um sistema de equações lineares 31

3.4 Atividade 4: Definições e propriedades de algumas figuras geométricas 34

3.5 Atividade 5: Medidas de tendência central e dispersão 37

4 Fragmentos matemáticos $\quad 40$

4.1 Atividade $1 \quad 40$

4.2 Atividade $2 \quad 43$

4.3 Atividade $3 \quad 46$

4.4 Atividade $4 \quad 50$

4.5 Atividade 5 61

5 Considerações finais $\quad 63$

A Apêndice - Decomposição em fatores primos 66

B Apêndice - Perpendicularidade entre o raio e a reta tan$\begin{array}{ll}\text { gente a um círculo } & 69\end{array}$

C Apêndice - Criando um problema a partir de um sistema $\begin{array}{ll}\text { de equações lineares } & 71\end{array}$

D Apêndice - Definições e propriedades de algumas figuras geométricas

E Apêndice - Medidas de tendência central e dispersão $\quad 75$ 


\section{Lista de figuras}

Figura 3.1 Aferição da medida da distância do ponto A até a reta $\mathrm{r} 28$

Figura 3.2 Resposta possível, traçando a perpendicular 29

$\begin{array}{lll}\text { Figura 3.3 Reta tangente ao círculo } & 29\end{array}$

Figura 3.4 Raios OD, OB e OE ressaltados em azul 31

Figura 3.5 Equações representadas no plano cartesiano 33

Figura 3.6 Quadrado, círculo e reta tangente aos dois 35

Figura 3.7 Ângulos retos ressaltados 36

$\begin{array}{lll}\text { Figura } 3.8 & \text { Gráfico de barras } & 38\end{array}$

Figura 4.1 Medida do segmento AB 43

Figura 4.2 Distância do ponto A à reta $\mathrm{r} \quad 44$

Figura 4.3 Triângulo ABC com dois ângulos retos 44

Figura 4.4 Segmentos que ligam o ponto A à reta $\mathrm{r} \quad 45$

Figura 4.5 reta $\mathrm{r}$ tangente ao círculo C no ponto T 45

Figura 4.6 Triângulo retângulo OPT e reta r secante ao círculo 46

Figura 4.7 Pontos A, B e C colineares 47

Figura 4.8 Retas r e s paralelas $\quad 49$

Figura 4.9 Retas r e s concorrente no ponto A 49

$\begin{array}{ll}\text { Figura 4.10 Retas r e s sobrepostas } & 50\end{array}$

Figura 4.11 Reta h transversal às paralelas f e g 51

Figura 4.12 Paralelogramo ABCD 52

Figura 4.13 Paralelogramo ABCD e suas diagonais AC e BD 52

Figura 4.14 Triângulos BAD e CDA congruentes 53

Figura 4.15 Losango ABCD $\quad 54$

Figura 4.16 Diagonais AC e BD formando ângulos retos 54

Figura 4.17 Esquema para demonstração da proposição $4.43 \quad 56$

Figura 4.18 Ângulos central e inscrito 56

Figura 4.19 Ângulos central e inscrito $\quad 57$

Figura 4.20 Teorema do ângulo externo $\quad 57$

Figura 4.21 Quadrilátero ABCD com ângulos opostos suplementares 58

Figura 4.22 Quadriláteros ABCD e ABCE $\quad 59$

Figura 4.23 Retas tangentes à circunferência $\quad 59$

Figura 4.24 Quadrilátero ABCD circunscrito a circunferência 60

Figura 4.25 Quadriláteros ABCD e ABCD' 61 


\section{Lista de tabelas}

$\begin{array}{lll}\text { Tabela 3.1 } & \text { Descrição da atividade } 1 & 24\end{array}$

$\begin{array}{lll}\text { Tabela 3.2 } & \text { Descrição da atividade } 2 & 28\end{array}$

Tabela 3.3 Descrição da atividade $3 \quad 31$

$\begin{array}{lll}\text { Tabela 3.4 Descrição da atividade } 4 & 34\end{array}$

$\begin{array}{lll}\text { Tabela 3.5 } & \text { Descrição da atividade } 5 & 37\end{array}$

$\begin{array}{lll}\text { Tabela 3.6 } & \text { Média de gols } & 37\end{array}$

Tabela 3.7 $\quad$ Distribuição de gols por jogo nos últimos 10 jogos 38

Tabela 3.8 Tabela com média, variância e desvio padrão 39

Tabela E.1 Média de gols $\quad 75$

Tabela E.2 Distribuição de gols por jogo nos últimos 10 jogos $\quad 75$ 


\title{
Lista de Abreviaturas
}

\author{
ALB - Associação de Leitura do Brasil \\ BNCC - Base Nacional Comum Curricular \\ COLE - Congresso de Leitura do Brasil \\ PCN - Parâmetros Curriculares Nacionais
}


Nós não podemos mudar as cartas que nos foram dadas, mas apenas o modo como iremos jogá-las.

Randy Pausch, A Lição Final. 


\section{Introdução}

Tornar a sala de aula um espaço de formação de cidadãos é um desafio que permeia toda a carreira docente. Elaborar estratégias, buscar meios de dialogar com o aluno e despertar o interesse dele nos conteúdos propostos é uma tarefa árdua que exige, muitas vezes, fugir do tradicionalismo ao qual estamos acostumados.

A fim de defender o uso do discurso oral e escrito na sala de aula de Matemática, o presente trabalho busca referenciais nos documentos oficiais que norteiam a Educação Básica brasileira, que são os Parâmetros Curriculares Nacionais (PCN) e a Base Nacional Comum Curricular (BNCC), além de autores que discorrem sobre a importância da oralidade e da escrita na aula de Matemática, tais como Barbosa(2006, 2008), Coura(2006), Marquez e Santos(2017), Nacarato(2008, 2012, 2013) e Penha(2008).

Nesta dissertação, buscamos refletir sobre as seguintes questões: é importante praticar a Língua Portuguesa, em sua forma escrita e falada, em sala de aula? É possível elaborar atividades que estimulem esta prática?

O objetivo deste trabalho é provocar reflexões sobre formas distintas de se argumentar matematicamente, além de propor uma coletânea de atividades que possam ser aplicadas, ou adaptadas, na sala de aula de Matemática, sendo estas atividades formuladas com o propósito de estimular o uso da escrita, ou da fala, pelo aluno, abrindo espaço para debate e gerando autonomia para que o aluno chegue às suas próprias conclusões.

No capítulo 2 fazemos a fundamentação teórica, justificando a relevância do tema, associando o mesmo à formação da cidadania, prevista pelos autores dos PCN e da BNCC como uma das funções da escola. Seguindo o referencial teórico, falamos especificamente sobre a oralidade e a escrita na sala de aula de Matemática, mostrando a importância de estimular as duas práticas.

No capítulo 3 são propostas cinco atividades permeando todos os anos do Ensino Fundamental e o Ensino Médio. Estas atividades são classificadas por ano de escolaridade, tomando como base o que está elencado na BNCC. As propostas de atividades são acompanhadas por respostas esperadas(mas não únicas) e comentários, relacionando as mesmas ao que foi tratado no capítulo anterior. Cabe ressaltar que o exercício da argumentação é foco primordial do 
presente trabalho.

No capítulo 4 são feitas algumas demonstrações, algumas definições são apresentadas, tomando como base as atividades que foram propostas, com o intuito de fornecer um texto mais completo aos colegas professores que venham consultá-lo.

No capítulo 5 fazemos nossas considerações finais sobre o trabalho, vislumbrando possíveis passos a serem dados a partir do mesmo. 


\section{2}

\section{Fundamentação teórica}

Alguns preconceitos permeiam diversas salas de aula em todo o Brasil. Um destes conceitos pré-estabelecidos impõe que a sala da aula de Matemática é um lugar onde se faz conta. Em diversas ocasiões, quando o professor propõe algo em que as tais "contas" não estão tão claras ou mesmo inexistem, provavelmente o docente ouvirá a seguinte pergunta: "quando começam as contas?". Essa tecnicalidade exacerbada na aula de Matemática já era alertada pelos autores dos Parâmetros Curriculares Nacionais(PCN):

Em nosso país o ensino de Matemática ainda é marcado pelos altos índices de retenção, pela formalização precoce de conceitos, pela excessiva preocupação com o treino de habilidades e mecanização de processos sem compreensão. [BRASIL, 1998, p.19]

Tendo em vista essa análise feita em um documento de 1998, documento este formativo para a educação básica brasileira até a homologação da Base Nacional Comum Curricular(BNCC) no final de 2018, percebemos que não é recente a preocupação em mudar o paradigma do ensino escolar de Matemática. Segundo Nacarato uma primeira tentativa de mudar o cenário alertado pelos autores do PCN veio, a nível mundial, em 1980 com algumas reformas curriculares nas quais:

questões relativas à alfabetização matemática e ao letramento foram destacadas como essenciais para os processos de comunicação e, consequentemente, de produção de sentidos e significados matemáticos.[NACARATO, 2013, p.64]

No mesmo texto o autor considera como um marco para a Educação Matemática brasileira a inclusão do Seminário de Educação Matemática no Congresso de Leitura do Brasil (COLE) no ano de 2003.

O COLE é um evento organizado pela Associação de Leitura do Brasil(ALB) desde 1978[FERREIRA, 2020, p.92] e continua sendo promovido atualmente. A $22^{\mathrm{a}}$ edição do COLE ocorreu entre os dias 02 e 06 de agosto de 2021 de forma remota. Verificando os anais do COLE, no site da $\mathrm{ALB}^{1}$, o Seminário de Educação Matemática está presente nas edições de 2003, 2005, 2007 e na edição de 2009 existiu uma mesa dedicada à "Leitura, Escrita e

${ }^{1}$ http://alb.org.br/anais-cole/ 
Educação Matemática". Nos eventos posteriores aparecem trabalhos referentes à Educação Matemática, porém não é citado uma mesa ou um seminário específico com essa temática. Nesta última edição, ao consultar os resumos ${ }^{2}$, nota-se que existe somente um trabalho referente à Matemática. O título do trabalho é: "As Narrativas Orais Como Parte De Um Processo De Pertença E De Responsividade Nas Aulas De Matemática", com autoria de Cidinéia da Costa Luvison.

A contínua produção destes trabalhos em um evento dedicado a leitura ressalta a importância dada por Nacarato deste congresso na história da Educação Matemática Brasileira. Porém a existência de somente um trabalho relacionado à Matemática no último evento, pode indicar que este é um tema que deve ser mais explorado no meio acadêmico.

\section{1}

\section{A aula de Matemática e a formação de cidadão críticos}

O documento normativo atual para a Educação Brasileira é a BNCC. Seus autores introduzem o texto sobre a área de Matemática com o seguinte trecho:

O conhecimento matemático é necessário para todos os alunos da Educação Básica, seja por sua grande aplicação na sociedade contemporânea, seja pelas suas potencialidades na formação de cidadãos críticos, cientes de suas responsabilidades sociais. [BRASIL, 2018, p.265]

Um ensino puramente técnico não é suficiente para formar o aluno como cidadão crítico e ciente de suas responsabilidades sociais, como esperam os autores da BNCC. Acreditamos que ao lançar mão de procedimentos repetitivos, sem a devida reflexão sobre o que está sendo feito, impõe-se ao aluno um papel passivo em sala de aula, podendo ocorrer que essa posição seja assimilada pelo aluno como algo normal, que está implícito no ambiente escolar. Com o passar do tempo vai ficando cada vez mais desafiador trazer, ou devolver, o aluno ao lugar de protagonismo que lhe é devido.

Manter o aluno como mero espectador em sala de aula pode criar resistência nele em relação à escola, lugar este que tem como um dos seus principais pilares a promoção da educação. Este afastamento pode impedir que o aluno alcance plenamente sua cidadania, visto que "a educação não é a chave para a transformação, mas é indispensável. A educação sozinha não faz, mas sem ela também não é feita a cidadania" [FREIRE, 1995, p.74].

Paulo Freire ressalta, em outro texto, que: "ensinar não é transferir conhecimento, mas criar as possibilidades para sua própria produção ou a

\footnotetext{
${ }^{2}$ https://nasnuv.com/ojs2/index.php/resumoscole/issue/view/1
} 
sua construção"[FREIRE, 2003, p.47]. O ensino, que é fundamental para que o aluno alcance a cidadania, deve ser feito de tal forma que o discente tenha a possibilidade de gerar conhecimento.

Barbosa, Nacarato e Penha inspirados por Alrø e Skovsmose(2006) dizem, em relação a comunicação na "Educação Matemática Tradicional", que: "Muitas vezes, essa comunicação se limita às perguntas do professor e às respostas dos alunos"[BARBOSA et al., 2008, p.81]. Isso acaba por reforçar alguns papéis na relação professor-aluno: o aluno passivo, só verbalizando dentro de um formato preestabelecido e o professor, detentor do saber e, consequentemente, detentor do discurso. Sem estímulo a expressão livre por parte do aluno, avaliar sua compreensão sobre determinado assunto, se torna uma tarefa deveras árdua.

O estímulo ao uso da Língua Portuguesa, em sua forma escrita ou falada, na aula de Matemática, através de atividades que propiciem a utilização dela, surge como uma metodologia possível de ser implementada, tendo em vista o objetivo de formar cidadãos críticos. Isto se dá pela liberdade que o uso de algo tão natural como a Língua Portuguesa fornece aos alunos, dando-lhes a oportunidade de expressar suas ideias e conclusões com suas próprias palavras, gerando conhecimento. Segundo Santos(2005) (apud BARBOSA, NACARATO, PENHA) a linguagem "atua como mediadora, integrando as experiências individuais e coletivas na busca da construção e apropriação dos conceitos abstratos estudados"[BARBOSA et al., 2008, p. 80]. A linguagem então atua de duas formas: como uma ponte interligando conceitos matemáticos com vivências individuais e coletivas e como alicerce para construção individual dos conceitos estudados.

As interseções entre Matemática e Língua Portuguesa são diversas e profundas. Na verdade, uma depende da outra:

Letras e números fazem parte do ferramental cognitivo humano como entes complementares, cooperantes. No limiar do raciocínio, Matemática e Língua Materna apresentam-se associadas, interdependentes.[COURA, 2006, p.4].

Outro paradigma que é rompido ao estimular o uso da Língua Portuguesa em sala de aula, é de que a Matemática é uma disciplina puramente técnica: "Impregnando-se da Língua Materna, a Matemática passa a transcender uma dimensão apenas técnica, adquirindo assim o sentido de uma atividade caracteristicamente humana" [MACHADO, 1989, p.165]. A prática da argumentação une de maneira direta a Matemática e a Língua Portuguesa. Munido de definições e propriedades advindas da Matemática, chega-se a conclusões por meio de demonstrações, escritas ou faladas, em Língua Portuguesa. É importante 
ressaltar que a argumentação é um passo anterior a demonstração formal, não sendo esperado que os alunos elaborem tais demonstrações:

Uma argumentação não é, contudo, uma demonstração. A argumentação é mais caracterizada por sua pertinência e visa ao plausível, enquanto a demonstração tem por objetivo a prova dentro de um referencial assumido. [BRASIL, 1998, p.70]

Ainda sobre a diferença entre argumentação (explicação) e demonstração, Balacheef ressalta que:

Chamamos de explicação o discurso que visa tornar compreensível o caráter de verdade, apresentado pelo locutor, de uma proposição ou de um resultado. As razões podem ser discutidas, recusadas ou aceitas. Chamamos prova uma explicação aceita por certa comunidade num determinado momento. Esta decisão pode ser objeto de um debate em que o significado é a exigência de determinar um sistema de validação comum aos interlocutores.

No contexto da comunidade matemática, apenas as explicações que adotam uma forma particular podem ser aceitas como provas. Elas são uma sequência de enunciados seguindo regras determinadas: um enunciado é conhecido como verdadeiro, ou é deduzido daqueles que o precedem por meio de uma regra de dedução tomada num conjunto bem definido de regras. Chamamos essas provas de demonstração.[BALACHEFF, 1987, p.147-148]

Com o objetivo de estimular esse tipo de argumentação na aula de Matemática e usá-la como ferramenta para que o aluno "reflita sobre seu próprio pensamento, ou seja, reflita criticamente sobre suas experiências matemáticas, possibilitando que o aprendizado se torne ativo e não passivo" [BARBOSA et al., 2008, p.82], defendemos que devemos formular atividades que demandem o uso da língua materna, dando espaço para o debate de ideias e exercício da argumentação, propiciando um ambiente escolar que promova a cidadania.

\section{2}

\section{A oralidade}

A fala é a ferramenta de comunicação mais utilizada em sala de aula. Através dela o professor discorre sobre os conteúdos, responde a eventuais dúvidas, se comunica com a turma.

Sobre a importância da comunicação em sala de aula Marquez e Santos afirmam que: 
A partir da comunicação os alunos têm a oportunidade de explorar, organizar e conectar seus pensamentos com os novos conhecimentos abstratos e simbólicos dessa área do conhecimento. Podem refletir sobre suas ideias, trocar com o outro, ouvir o outro e relacionar sua ideia ou conceito. Têm a oportunidade de compreender coisas, melhorar conceitos e esclarecer dúvidas. Podem também descrever suas observações, pensar sobre os assuntos para justificar e registrar seus pensamentos de como chegar à solução de um problema. A compreensão, o esclarecimento e a organização são acentuados. Quanto mais se comunica, melhor se compreende, pois, a comunicação é o meio usado por todas as pessoas para aprender conceitos, informações e representações. Isso faz com que os alunos tenham uma aprendizagem mais significativa, relacionando e associando diferentes significados a uma nova ideia.[MARQUEZ \& SANTOS, 2017, p.5136]

A sala de aula é um espaço coletivo. Mediante isto a comunicação deve ser inerente à este espaço e a oralidade é, para os alunos ouvintes, a mais acessível forma de comunicação. Estimular o diálogo é uma forma de coletivizar a aprendizagem. Segundo Nacarato:

a oralidade é imprescindível para a elaboração conceitual em matemática, por colocar em movimento a circulação de significações em sala de aula, possibilitando a apropriação de um vocabulário matemático, além de modos de argumentação.[NACARATO, 2012, p.11]

Marquez e Santos descrevem, baseando-se em Cândido(2001), que a comunicação na aula de Matemática ocorre de três formas: oral, por desenhos ou escrita. Falando especificamente sobre oralidade é dito que este é um recurso "simples, prático, direto e pode ser iniciado e interrompido facilmente. Pode ser usado por qualquer idade, mesmo quando não há a presença da escrita"[MARQUEZ \& SANTOS, 2017, p.5136], ressaltando então a maleabilidade deste recurso, indicando que ele pode e deve ser utilizado sem restrições.

Schliemann et al.(2006) (apud FREITAS e GONÇALVES) comparou, em seu estudo, a comunicação oral e escrita, chegando a seguinte conclusão:

A maior facilidade do procedimento oral em comparação com o escrito era evidente especialmente quando as crianças não conseguiam resolver algum problema através do procedimento escrito ensinado pela escola, mas imediatamente encontravam a solução quando o examinador sugeria-lhes que usasse o procedimento oral.[FREITAS \& GONÇALVES, 2020, p.3]

Das diversas formas de comunicação que adquirimos ao longo da vida a fala é a primeira e principal forma de interação. Antes de escrever, nós aprendemos a falar. Então é plausível que antes de escrever na aula de Matemática, seja dada a oportunidade de se falar sobre o que se quer escrever ou sobre o que se quer concluir. Uma fala que de ínicio deve ocorrer sem 
preconceitos, sem limitar os discursos a categorizações de certo ou errado.

Segundo Ponte e Sousa, inspirados por Bishop e Goffree(1996):

é através do discurso oral que o professor regula o essencial do trabalho da sala de aula, sendo também através dele que se realiza o essencial do processo de negociação de significados matemáticos entre professor e alunos. [PONTE \& SOUSA, 2010, p.33]

Por muitas vezes o professor se omite de fazer essa "negociação de significados"com os alunos, escrevendo definições no quadro, que estão matematicamente corretas, mas que o aluno não gerou significado sobre elas. Palavras que tem certo significado no cotidiano, são ressignificadas no contexto da sala de aula. Essa ressignificação deve vir juntamente com um debate sobre o novo entendimento dessa palavra, agora em um novo contexto. Um exemplo são os conceitos de numerador e denominador de uma fração. Ao apresentar esses conceitos, deveria se questionar aos alunos se para eles já existe algum significado para essas palavras. Havendo uma negativa por parte deles, pode se tentar falar palavras similares que tragam o mesmo sentido. Partindo do exemplo dado, se pode perguntar aos alunos qual o significado de enumerar e denominar. Se ainda assim os alunos não tiverem algum entendimento anterior sobre essas palavras, deve-se explicar o sentido mais global delas e depois trazer este sentido para o contexto das frações. Se não houver este diálogo, corre-se o risco de que essas denotações fiquem sem sentido nenhum para os alunos, dando a impressão, para eles, que se fosse escolhido qualquer outro termo, não faria diferença alguma.

Dando maior profundidade ao assunto, Vigostski(2001) (apud NACARATO) escreveu que:

Em qualquer idade, um conceito expresso por uma palavra representa uma generalização. Mas os significados das palavras evoluem. Quando uma palavra nova, ligada a um determinado significado, é apreendida pela criança, o seu desenvolvimento está apenas começando. [...] Esse processo de desenvolvimento dos conceitos ou significados das palavras requer o desenvolvimento de toda uma série de funções como a atenção arbitrária, a memória lógica, a abstração, a comparação e a discriminação, e todos esses processos psicológicos sumamente complexos não podem ser simplesmente memorizados, simplesmente assimilados.[NACARATO, 2012, p.14]

Não se devem ignorar as etapas da assimilação de um conceito novo. O aluno pode simplesmente decorar algo que foi falado pelo professor em sala de aula, sem ter entendido praticamente nada do que foi passado. A comunicação em sala de aula não pode ignorar o aluno como participante ativo.

Ainda, segundo Nacarato, é importante que o professor, enquanto me- 
diador do conhecimento em sala de aula, proponha tarefas que mobilizem os alunos a discuti-las e resolvê-las. Os alunos vão querer falar sobre algo que gere neles interesse. Não será qualquer tarefa que terá esse efeito.

A postura indagadora e problematizadora do professor, como mediador do processo, é fundamental. Ele precisa aprender a dar tempo para os alunos se colocarem, expressarem suas ideias, evitando dar respostas prontas, mas sempre instigando o grupo com novas questões. Um professor questionador promove o desenvolvimento de alunos também questionadores e autônomos intelectualmente.[NACARATO, 2012, p.25]

Mesmo sem atividades com a finalidade especifica de estimular o aluno a falar, a postura do professor por si só, já incentiva e encoraja os alunos a contribuir verbalmente na aula.

A escola é um lugar onde são dadas algumas respostas, porém não se deve fugir da responsabilidade de ser a escola um local onde surgem questionamentos. Tanto o surgimento de questões, como a busca por soluções devem ser estimulados, utilizando a oralidade inerente a sala de aula para mediar essas discussões.

\section{3}

\section{A escrita}

Analisando especificamente a questão da escrita é dito que "ela promove processos metacognitivos - o aluno reflete sobre sua própria aprendizagem no ato de escrever - e produz outros sentidos para a matemática"[BARBOSA et al., 2008, pg.81]. A escrita surge como uma ferramenta essencial pois, através dela, o aluno atribui significado ao conteúdo com que ele teve contato. Existe um caminho a ser percorrido entre ter o primeiro contato com o conteúdo e atribuir significado para o mesmo. A escrita é uma ferramenta capaz de auxiliar o aluno a percorrer este caminho.

A escrita também auxilia o papel de avaliador do professor pois ele "pode identificar a apropriação adequada ou não dos conceitos que estão sendo trabalhados e os significados que são atribuídos a esses conceitos"[BARBOSA et al., 2008, p.80]. A produção escrita do aluno vai expandir a percepção do docente sobre qual significado os alunos atribuíram ao que foi dito em sala de aula. Lançando mão dessas informações, pode-se fazer ajustes, intervenções ou até mudanças no planejamento, visando melhorar a comunicação e compreensão dos conteúdos abordados.

\section{Segundo Freitas(2006) (apud BARBOSA, NACARATO, PENHA)}

a escrita promove processos metacognitivos - o aluno reflete sobre sua própria aprendizagem no ato de escrever - e produz outros sentidos para a matemática. [BARBOSA et al., 2008, p.81] 
Existe um processo de autoavaliação por parte do aluno, quando o mesmo é estimulado a escrever. A existência do registro escrito dá a oportunidade ao professor de questionar o aluno sobre o que ele escreveu. Como fruto deste diálogo podem surgir novas concepções, podem ser verificados possíveis ruídos de comunicação e por fim, se necessário, pode ser feita uma reescrita, oportunizando ao aluno registrar suas ideias reformuladas.

Outro tipo de atividade onde pode ser utilizada a escrita como metodologia é a produção de problemas pelos próprios alunos. Alrø e Skovsmose(2006) (apud BARBOSA, NACARATO, PENHA) escrevem que:

Geralmente, exercícios de Matemática são preparados por uma autoridade externa à sala de aula. Nem o professor, nem o aluno participam da elaboração dos exercícios. Eles são estabelecidos pelo autor de um livrotexto. Isso significa que a justificativa para a relevância dos exercícios não faz parte da lição em si mesma. Os textos e exercícios matemáticos costumam ser, para aqueles que vivenciam a prática e a comunicação em sala de aula, elementos preestabelecidos. [BARBOSA et al., 2008, p.81]

Se limitar somente a resolução de exercícios propostos no material didático pode afastar o aluno da compreensão do que está sendo tratado, visto que existe um distânciamento entre o que é proposto ali e a sala de aula, onde nenhum dos integrantes teve participação na formulação das atividades. O professor pode usar alguma atividade do material didático como base e reescrevê-la de forma a estimular a escrita do aluno, deixando algumas respostas abertas sem ter como resultado uma quantidade, podendo gerar debates de ideias acerca do que foi escrito pelos alunos.

A argumentação costuma ser pouco explorada em atividades nos livros didáticos, mesmo sendo a argumentação um dos pilares do fazer matemático. Os resultados costumam aparecer prontos ou seguidos de uma justificativa que por vezes não faz sentido nenhum ao aluno. É retirada a oportunidade do aluno chegar a tais conclusões e fazer seus registros sobre elas e os meios que o levou a chegar aos resultados.

Quando o aluno cria o hábito da escrita, adquire domínio para repensar sobre suas idéias, para construir e reconstruir o significado e, nesse caso, o discurso passa de expressivo para argumentativo.[BARBOSA et al., 2008, p.83]

Essa mudança no tipo de discurso é fundamental, pois o aluno adquire autoridade para falar sobre o assunto. Autoridade esta que estava posta somente sobre o professor e o livro didático. Munido desta autoridade o aluno pode usar esse ferramental na resolução dos exercícios e problemas tradicionais.

Não é uma ruptura epistemológica simples: 
O objetivo da escrita na aula de matemática é o desenvolvimento da cognição matemática do aluno. O trabalho não é fácil nem para os alunos nem para os professores, pois os textos individuais ou coletivos têm a forma e o conteúdo dados por seu produtor, e não o que o professor deseja que conste neles. [BARBOSA et al., 2008, p.84]

A escrita dos alunos pode revelar concepções equivocadas que, na visão do professor, já estariam bem consolidadas dentro do seu planejamento. Essa revelação pode ser desagradável por demandar do professor um redirecionamento, podendo até ser necessário que se recomece o processo de outra forma. Por outro lado, a escrita dos alunos pode surpreender, revelando soluções criativas e reflexões interessantes sobre os conteúdos. Os ganhos desta abordagem metodológica são inestimáveis, visto que estimular os alunos a escrever não somente revela equívocos, mas sedimenta e traz à luz novos conhecimentos. 


\section{3}

\section{Atividades Propostas}

Com base no que foi discutido acima, acreditamos na importância da presença, na aula de Matemática, de atividades que estimulem o uso da linguagem oral e escrita. Isso pode ser feito em diversas situações e com diferentes conteúdos. O presente trabalho sugere algumas atividades com esse foco, esperando que sirva de inspiração para que os professores da Escola Básica adaptem as apresentadas e criem outras sempre com o olhar voltado para o aluno. Sugerimos algumas atividades a seguir e, juntamente com elas, algumas respostas possíveis. Ressaltamos que estas respostas são apenas para nortear o leitor, deixando a cargo do professor a avaliação de diferentes estratégias de resolução em conjunto com os alunos, visto que podem aparecer diversas soluções quando deixamos fluir a criatividade dos discentes.

O ano de escolaridade ao qual se destina cada atividade é sugerido tomando como base a divisão de conteúdos contida na BNCC, sendo ressaltado nos comentários a habilidade que melhor se aproxima ao que é proposto.

As atividades, sem comentários e sugestões de soluções, estão disponíveis nos apêndices deste trabalho, em formato pronto para aplicação.

\section{1}

\section{Atividade 1: Decomposição em fatores primos}

Tabela 3.1: Descrição da atividade 1

\begin{tabular}{|c|c|c|}
\hline Conteúdo & Ano de escolaridade & Objetivo \\
\hline Números primos & $6^{\mathrm{o}}$ Ano & $\begin{array}{l}\text { Construir significado para o conceito } \\
\text { de número primo e número composto }\end{array}$ \\
\hline
\end{tabular}

- Parte 1

Responda as seguintes questões:

a) Explique, com suas palavras, o que é matéria prima;

b) Cite alguns exemplos de objetos ou produtos e suas matérias primas; 
c) Você já ouviu falar sobre números primos? Descreva que ideia vem em seu pensamento ao ouvir que um número é primo;

\section{Respostas possíveis:}

a) Matéria prima é algo pronto que se utiliza para produzir outras coisas;

b) Um bolo pode ter como matéria prima ovo, manteiga, farinha, açúcar e ovos. Uma mesa pode ter como matéria prima madeira e parafusos;

c) Já ouvi falar. Eu pensei na relação familiar, porém depois vi que eram números naturais que têm exatamente dois divisores naturais: o 1 e ele mesmo.

- Parte 2

a) Vamos fazer algumas contas! Vamos tentar escrever os números a seguir como produto da maior quantidade possível de números naturais diferentes de 1 . Vamos observar o exemplo abaixo:

Exemplo: O número 56 pode ser escrito como o produto dos números 7 e $8(7 \cdot 8=56)$. Agora vamos pensar se é possível fazer o mesmo com os números 7 e 8 . Sabemos que $8=4 \cdot 2$. Logo, podemos escrever $7 \cdot 4 \cdot 2=56$. Como $4=2 \cdot 2$ podemos escrever $7 \cdot 2 \cdot 2 \cdot 2=56$. Antes de fazer o mesmo com outros números, responda: Seria possível continuar o processo dado no exemplo? Justifique sua resposta. Agora faça o mesmo para os números: 12, 18, 23, 30 e 189;

b) Foi possível realizar o procedimento em todos os números? Se não, descreva qual foi a dificuldade encontrada?

c) Você percebe alguma característica comum aos números encontrados no fim de cada procedimento? Se houver essa característica, explique sobre ela;

d) Dentre os Números Naturais, existem mais números com essa característica? Se houver, apresente alguns desses números;

\section{Respostas possíveis:}

a) Não, pois não existem dois números naturais diferentes de 1 em que o produto é 2 ou 7 .

$12=2 \cdot 2 \cdot 3$

$18=2 \cdot 3 \cdot 3$ 
Não é possível com o 23

$30=2 \cdot 3 \cdot 5$

$189=3 \cdot 3 \cdot 3 \cdot 7$

b) Não foi possível com o 23. Não consegui encontrar dois números naturais, diferentes de 1 , cujo produto fosse 23 ;

c) Sim. Assim como aconteceu com o 2, 7 e o 23, não foi possível encontrar dois números naturais, sem utilizar o 1 , para que o produto entre eles fosse igual aos números que restaram no final dos processos;

d) Sim. 11, 13, 17, 19, ...

- Parte 3

a) Procure o significado da palavra composto e explique o que você entendeu;

b) De acordo com o que foi trabalhado na "Parte 2", podemos dizer que existem números que são compostos por outros? Explique e cite alguns exemplos;

c) Explique como um número pode ser considerado matéria prima para compor novos números;

d) Faça a sua definição de número primo e de número composto. Existe algum Número Natural que não é primo e nem composto? Explique.

\section{Respostas possíveis:}

a) Formado de diversas partes; que se $\operatorname{compôs}^{1}$; aquilo que resulta da junção de várias e distintas coisas.

b) Sim. O 30 é composto pelo produto de 2,3 e 5 . O 45 é composto pelo produto de 3,3 e 5 .

c) Através destes números que encontramos e vimos que não podem ser escritos como produto de dois números naturais diferentes de 1 , podemos compor outros números através do produto entre eles.

d) Um número primo é um número que não pode ser escrito como resultado da multiplicação de dois números naturais diferentes de 1. Logo, um número primo tem exatamente dois divisores naturais. Eles podem ser usados como matéria prima para formar outros números através da multiplicação entre números primos. Estes

\footnotetext{
${ }^{1}$ https://www.dicio.com.br/composto/
} 
números são chamados de compostos. O número 1 só é resultado de multiplicações de números naturais que sejam todos iguais a 1 , logo ele não é composto. Ele também não pode ser considerado primo, pois tem exatamente um divisor natural. O zero também não é primo e nem composto, pois ele tem infinitos divisores e, para que um produto seja zero, o próprio zero deve ser um dos fatores.

\section{Comentários:}

Costumeiramente se fala de números primos no $6^{\circ}$ ano e no $7^{\circ}$ ano este conceito é abordado juntamente com o estudo sobre múltiplos e divisores de números naturais, como forma de introduzir os algoritmos para cálculo do Maior Divisor Comum (MDC) e Menor Múltiplo Comum (MMC). A classificação dos conteúdos do $6^{\circ}$ ano na BNCC, dentro do Objeto de Conhecimento: Números primos e compostos a habilidade (EF06MA05) "Classificar números naturais em primos e compostos, estabelecer relações entre números, expressas pelos termos "é múltiplo de", "é divisor de", "é fator de"..."[BRASIL, 2018, p.300 e 301], corrobora com a intencionalidade já citada de falar sobre primalidade de Números Naturais como preparação para os conceitos de múltiplos e divisores.

Ao classificar alguns Números Naturais como primos somente com a intenção de servirem de ferramentas para fazer divisões sucessivas e auxiliar com o cálculo do MMC e do MDC perdemos a oportunidade de criar significado ao conceito de número primo.

Na primeira parte da atividade a intenção é verificar se já existe algum significado prévio para o aluno em relação ao termo "matéria prima"opondo isso ao pensamento que ele teve ao ouvir falar o termo "número primo". Provavelmente muitos alunos associam a palavra primo ao sentido parental da mesma. Não ocorrendo uma negociação de significados o aluno pode perceber por si próprio que o sentido da palavra "primo"não tem a ver com a relação familiar e somente irá aceitar essa palavra no contexto matemático, pensando que ela está totalmente dissociada de um contexto mais amplo. Esta parte pode ser feita de forma escrita, porém deve se dar a oportunidade para que os alunos exponham suas respostas e comparem os significados que cada um deles carrega em relação aos termos que foram apontados.

Na segunda parte a ideia é utilizar um conhecimento prévio do aluno (multiplicação) e a partir disto fazer a decomposição de um número natural em fatores primos sem algoritmos, fazendo a decomposição número a número até não ser mais possível. A partir do item (b) o aluno já está sendo levado a reflexão sobre algumas diferenças entre os números que aparecem, sendo estas diferenças subsídios para classificar Números Naturais que tem ou que não tem certas características. 
Na terceira parte é feita uma tentativa de consolidar um novo significado para a palavra primo, agora ganhando um significado atrelado à matéria prima com a qual podemos compor outros números que, por este motivo, os chamaremos de compostos, com esta palavra tendo o significado dentro da Matemática mais próximo do significado habitual na Língua Portuguesa.

\section{2}

\section{Atividade 2: Perpendicularidade entre o raio e a reta tangente a um círculo}

Tabela 3.2: Descrição da atividade 2

\begin{tabular}{|c|c|c|}
\hline Conteúdo & Ano de escolaridade & Objetivo \\
\hline Geometria plana & $7^{\circ}$ ano & $\begin{array}{c}\text { Observar que uma reta } \\
\text { tangente ao círculo é } \\
\text { perpendicular ao raio no } \\
\text { ponto de tangência }\end{array}$ \\
\hline
\end{tabular}

- Parte 1

Observe a Figura 3.1 e meça, com uma régua, a distância do ponto A até a reta $\mathrm{r}$ nas duas situações. Ao medir, trace o segmento de reta que você usou para aferir a medida.

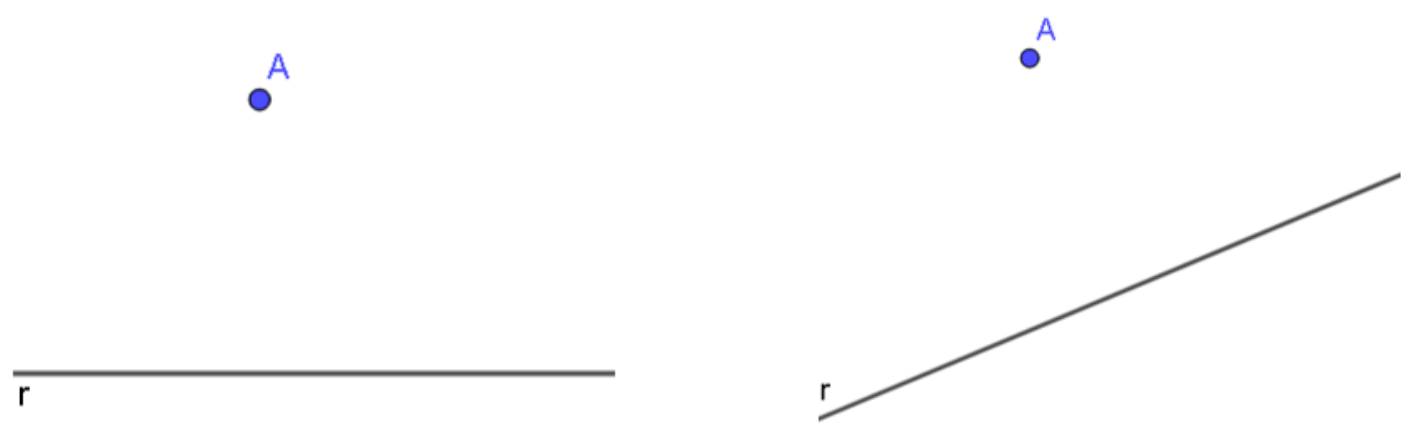

Figura 3.1: Aferição da medida da distância do ponto A até a reta r

Escreva o processo que você utilizou para aferir as medidas nos dois casos.

Resposta possível: Nos dois casos, a partir do ponto A, tracei o segmento que forma $90^{\circ}$ com a reta $\mathrm{r}$. Depois aferi, com a régua, a medida do segmento que tracei.

- Parte 2 

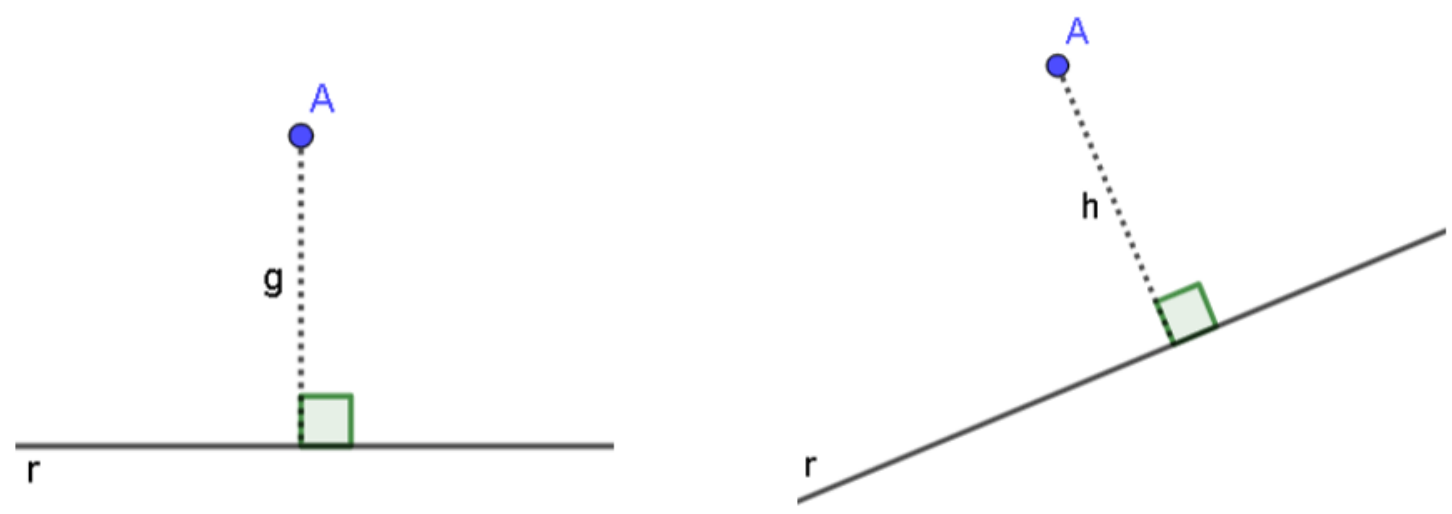

Figura 3.2: Resposta possível, traçando a perpendicular

Observe a Figura 3.3, em que está representado um círculo de centro O e uma reta tangente a este círculo no ponto $\mathrm{B}$, e responda as seguintes questões:

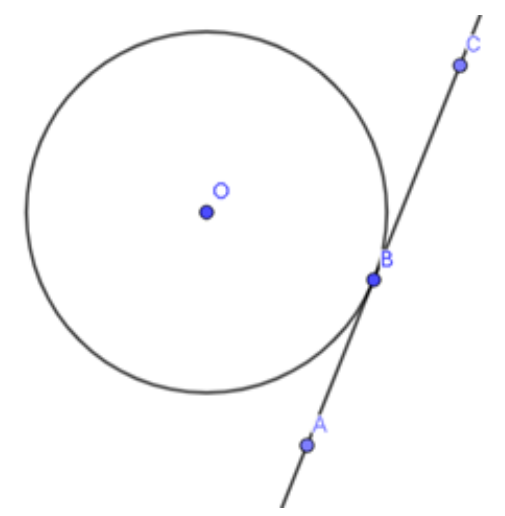

Figura 3.3: Reta tangente ao círculo

a) Descreva em que situação uma reta é tangente a um círculo;

b) Qual dos pontos A, B ou C, da reta, está mais próximo do centro O? Explique sua resposta;

c) Existe algum ponto na reta, diferente dos pontos já marcados, que seja o mais próximo do centro O? Justifique;

d) Trace o segmento entre o centro $\mathrm{O}$ e o ponto da reta que é o mais próximo deste centro. Qual o ângulo entre esse segmento e a reta?

\section{Respostas possíveis:}

a) Uma reta é tangente a um círculo, quando existe somente um ponto de interseção entre eles; 
b) $\mathrm{O}$ ponto $\mathrm{B}$, pois a distância entre $\mathrm{B}$ e $\mathrm{O}$ é igual ao raio do círculo, visto que $\mathrm{B}$ pertence a circunferência. Como A e C estão externos ao círculo, a distância deles em relação à $\mathrm{O}$ é maior que o raio;

c) Não. B é o ponto mais próximo, pois este é o único ponto da reta que também pertence ao círculo. Todos os outros pontos da reta são exteriores ao círculo e, por este motivo, a distância entre o centro O e estes pontos é maior que o raio, logo são distâncias maiores que a medida do segmento OB.

d) É o ângulo reto, pois vimos na "Parte 1"que o menor segmento entre um ponto e uma reta é o segmento perpendicular que liga este ponto à reta.

\section{Comentários:}

Embora esse resultado não conste diretamente entre os Objetos de Conhecimento na BNCC, vamos classificar esta atividade dentro de $A$ circunferência como lugar geométrico na habilidade (EF07MA22) "Construir circunferências, utilizando compasso, reconhecê-las como lugar geométrico e utilizá-las para fazer composições artísticas e resolver problemas que envolvam objetos equidistantes."[BRASIL, 2018, p.308 e 309]. Caso os alunos não tenham conhecimento sobre retas tangentes ao círculo, pode ser proposto que os alunos construam uma circunferência com compasso, marquem um ponto nela e tracem retas passando por este ponto, questionando se é possível traçar uma reta que só intercepte a circunferência neste ponto. Essa será a reta tangente.

Na parte 1, o objetivo é verificar como os alunos entendem que se deva medir a distância entre ponto e reta. É importante ressaltar a unicidade da distância, observando que dos infinitos segmentos de reta que ligam o ponto A à reta, existe um deles que é menor que todos os outros e este forma ângulo de $90^{\circ}$ com a reta. É interessante perguntar aos alunos como é feita a medida da altura de uma pessoa gerando um debate de ideias, mediando para que desse debate possam surgir conclusões que posteriormente serão escritas como resposta à atividade. Ao fazer isso está sendo estimulada a oralidade dos alunos oportunizando ressignificar um conhecimento deles e transferindo essa compreensão para o conteúdo que se deseja abordar. Como foi tratado no capítulo anterior, estimular os alunos a debaterem suas ideias e socializar seus conhecimentos irá dar subsídios para a escrita, enriquecendo a mesma.

Na parte 2, a intenção é que o aluno já esteja a par das posições relativas entre reta e círculo, por isso é pedido no item (a) que ele descreva uma destas posições, sendo importante que ele use seu linguajar próprio, como forma de sedimentar a compreensão das definições. No item (b) o aluno já pode 
traçar os segmentos OA e OC para a partir destes formar sua argumentação escrita e responder à questão. Caso nenhum aluno tenha usado a medida do raio do círculo para argumentar, pode-se usar a Figura 3.4 para ajudar na argumentação e explicação. Como $\mathrm{OB}=\mathrm{OD}=\mathrm{OE}$, OB é menor que OC e OA.

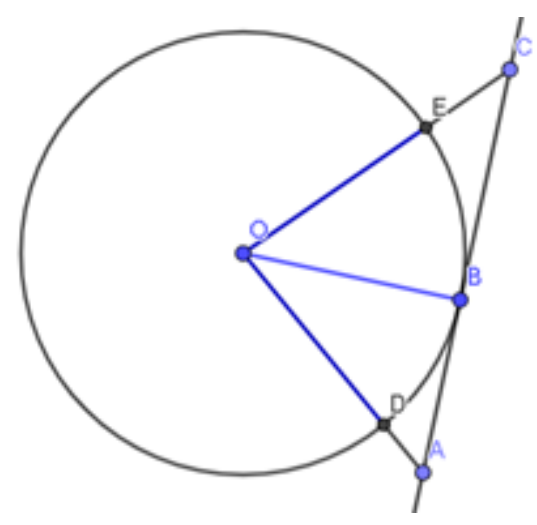

Figura 3.4: Raios OD, OB e OE ressaltados em azul

Nos itens (c) e (d) é esperado que se use o que foi discutido na questão 1 no desenvolvimento da argumentação para chegar à conclusão de que o ângulo entre $\mathrm{OB}$ e a reta é $90^{\circ}$. É importante que os alunos tenham a tranquilidade de testar diferentes estratégias argumentativas, podendo ocorrer que eles recorram a intuição em alguns momentos. Essa é mais uma oportunidade de estimulá-los a se expressar, compartilhando com o restante da turma suas percepções. Possíveis erros podem acabar sendo sanados naturalmente durante as discussões e a resposta (no caso o ângulo de $90^{\circ}$ ) pode acabar surgindo.

\section{3}

Atividade 3: Criando um problema a partir de um sistema de equações lineares

Tabela 3.3: Descrição da atividade 3

\begin{tabular}{|c|c|c|}
\hline Conteúdo & Ano de escolaridade & Objetivo \\
\hline \multirow{2}{*}{$\begin{array}{c}\text { Sistema de equações } \\
\text { lineares }\end{array}$} & $8^{\circ}$ ano & Incentivar os alunos a \\
& escreverem um problema a \\
partir de um sistema de \\
equações lineares, \\
& $\begin{array}{c}\text { estimulando a criatividade e } \\
\text { a transferência da } \\
\text { linguagem matemática para } \\
\end{array}$ & a materna \\
\hline
\end{tabular}


Observe o sistema de equações abaixo e faça o que é proposto a seguir: $\left\{\begin{array}{c}20 x-10 y=100 \\ x+y=80\end{array}\right.$

a) Crie um problema de tal forma que a solução possa ser modelada pelo sistema de equações dado.

b) Qual o significado das variáveis x e y no problema que você criou?

c) Como você resolveria este sistema? Resolva-o e explique a escolha do método que você utilizou.

d) Represente a situação apresentada no plano cartesiano, explicando o que a posição relativa entre as retas representa em relação à resolução do sistema de equações.

\section{Respostas possíveis:}

a) Em um jogo, uma pessoa ganha 20 pontos por acerto e perde 10 pontos a cada erro. Sabendo que a pessoa fez 100 pontos em 80 jogadas, determine a quantidade de acertos e de erros desta pessoa;

b) x - número de acertos da pessoa; y - número de erros da pessoa;

c) Vou resolver o sistema multiplicando a segunda equação por 10 e depois somando as duas, obtendo assim a equação $30 x=900$. Isolando o $x$ encontro que $x=30$. Substituindo esse resultado em $x+y=80$ encontro que $y=50$. Utilizei este método pois foi fácil eliminar uma das incógnitas só multiplicando a segunda equação por 10 e depois somando as duas.

d) Ao representar as duas equações no plano cartesiano, são geradas duas retas concorrentes. Isso quer dizer que existe um par ordenado (x,y), o ponto onde estas retas concorrem, que satisfaz as duas equações. 


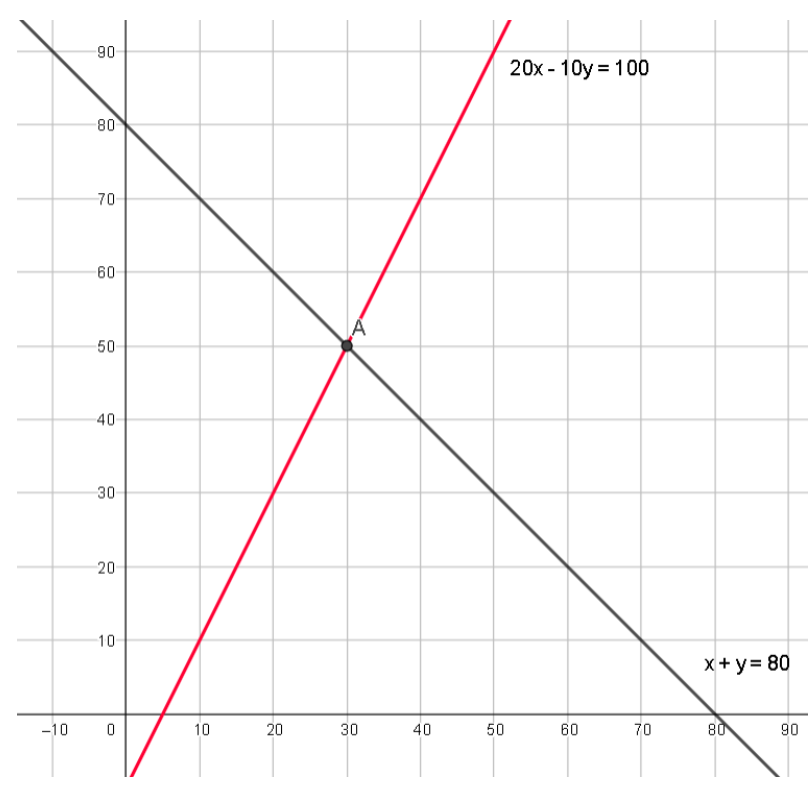

Figura 3.5: Equações representadas no plano cartesiano

\section{Comentários:}

Sistemas de equações lineares é um tópico pertencente ao $8^{\circ}$ ano pela divisão feita na BNCC. Esta atividade se enquadra no Objeto de Conhecimento: Sistema de equações polinomiais de $1^{\circ}$ grau: resolução algébrica e representação no plano cartesiano e tem como habilidade (EF08MA08):

"Resolver e elaborar problemas relacionados ao seu contexto próximo, que possam ser representados por sistemas de equações de $1^{\mathrm{O}}$ grau com duas incógnitas e interpretá-los, utilizando, inclusive, o plano cartesiano como recurso."[BRASIL, 2018, p.312 e 313]

Nesta atividade é explorada a resolução e elaboração de problemas que envolvam sistemas de equações do $1^{\circ}$ grau. Esta habilidade descrita na BNCC vai de encontro com o que foi tratado no capítulo anterior, onde foi ressaltada a importância da produção de problemas pelos agentes da sala de aula, fazendo com que os problemas ganhem maior significado no contexto daquela turma.

A principal proposta da atividade é fazer com que o aluno percorra o caminho inverso ao que é feito tradicionalmente, fazendo com que ele crie significado para o sistema de equações. Ao fazer isto, ele está expressando sua criatividade de forma escrita. Além disso, deve ser dada a oportunidade para que os alunos compartilhem os problemas criados, trocando os problemas entre si e pedindo que os mesmos ajudem um ao outro na compreensão do que cada um escreveu.

O item (b) pode auxiliar o aluno a verificar algum equívoco na escrita, pois ao refletir sobre o significado de cada variável de acordo com o problema 
que ele criou, ele pode perceber se a situação proposta se adequa realmente ao sistema de equações.

O item (c) faz o aluno refletir na escolha do método que ele acredita ser o mais apropriado para solucionar o sistema dado. Isso gera autonomia no aluno para escolher a melhor dentre as ferramentas que ele possui e ao justificar sua escolha ele deve refletir sobre os métodos que aprendeu. Como foi dito no referencial teórico a escrita tem papel fundamental na assimilação dos conteúdos que são passados para o aluno em aula.

Após escolher a o método de resolução o aluno irá resolver esse sistema. Saber resolver sistemas de equações lineares e efetuar cálculos são coisas importantes. Porém ao optar por uma metodologia de repetição de exercícios similares com posterior resolução de problemas onde os alunos não tiveram participação na elaboração, perde-se uma grande oportunidade de que o aluno atribua significado aos conteúdos.

Ao pedir, no item (d), a representação gráfica do sistema de equações no plano cartesiano, queremos entender qual a interpretação do aluno em relação à posição relativa entre as retas que representam as equações do sistema. As duas equações, separadamente, tem infinitas soluções representados por pares ordenados associados a pontos que estão alinhados. Destes infinitos pontos, existe um em comum às duas, sendo o par ordenado associado a este ponto, solução das duas equações simultaneamente.

Nesta atividade apareceu tanto a resolução de problemas (criados pelos alunos) quanto a solução algébrica do sistema em si, contemplando também a representação geométrica, tudo isso sendo feito oportunizando a troca de conhecimentos e geração de sentido.

\section{4}

\section{Atividade 4: Definições e propriedades de algumas figuras geométricas}

Tabela 3.4: Descrição da atividade 4

\begin{tabular}{|c|c|c|}
\hline Conteúdo & Ano de escolaridade & Objetivo \\
\hline Geometria plana & $9^{\circ}$ ano & $\begin{array}{c}\text { Praticar a argumentação } \\
\text { através da }\end{array}$ \\
& $\begin{array}{c}\text { revisão de definições e } \\
\text { propriedades do círculo, } \\
\text { do quadrado e do trapézio }\end{array}$ \\
\hline
\end{tabular}


Observe a Figura 3.6, em que estão representados um quadrado e um círculo, tangentes no ponto $\mathrm{C}$. O círculo é tangente à reta $\mathrm{r}$ no ponto $\mathrm{B}$ e esta reta contém o lado DE do quadrado. Com base nessas informações responda:

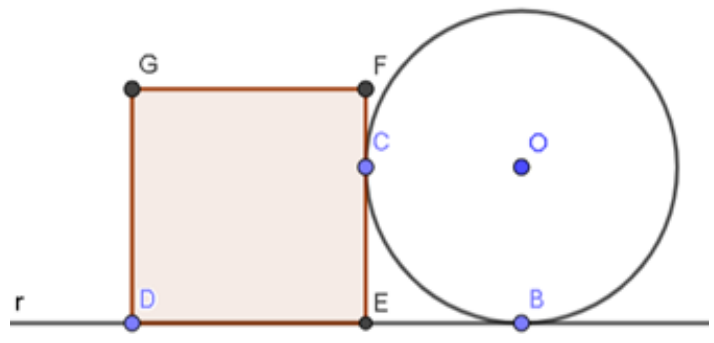

Figura 3.6: Quadrado, círculo e reta tangente aos dois

a) Descreva o que caracteriza um quadrado;

b) É possível formar outro quadrado com os pontos denotados por B, C, D, E, F, G e O na Figura 3.6? Justifique;

c) Quantos triângulos retângulos você consegue formar com os pontos denotados na Figura 3.6? Justifique;

d) "Os segmentos DF e EO são paralelos." Esta sentença é verdadeira ou falsa? Argumente;

e) Escreva a definição de trapézio e verifique se é possível construir um trapézio com os pontos denotados na Figura 3.6.

\section{Respostas possíveis:}

a) Um quadrado é um quadrilátero com os quatro lados com mesma medida e todos os ângulos internos retos;

b) Sim. O quadrado COBE. OC é perpendicular a EF, pois $\mathrm{OC}$ é raio do círculo e $\mathrm{C}$ pertence a $\mathrm{EF}$ que é tangente ao círculo. De forma análoga, $\mathrm{OB}$ é perpendicular a reta r. O ângulo $\mathrm{CE} B$ é reto, pois é suplemento de CÊD. Logo CÔB também é reto pois a soma dos ângulos internos de COBE é $360^{\circ}$. Logo COBE é um retângulo. Como OC e OB são raios do círculo, eles tem a mesma medida e como vimos que COBE é retângulo e todo retângulo tem lados opostos de mesmo tamanho, temos que todos os lados de COBE tem a mesma medida. Logo COBE é quadrado.

c) 13 triângulos retângulos (CED, CFG, GDE, GFE, DGF, FED, OCE, OBE, CEB, COB, FCO, GEO, FEB). Os ângulos OCE e OBE são retos 
pois a reta $\mathrm{r}$ e o segmento EF são tangentes ao círculo, $\mathrm{OC}$ e $\mathrm{OB}$ são raios do círculo. O ângulo $\mathrm{G} \hat{E} \mathrm{O}$ é reto pois $\mathrm{G} \hat{E} \mathrm{~F}=\mathrm{O} \hat{E} \mathrm{~F}=45^{\circ}$ e $\mathrm{G} \hat{E} \mathrm{O}$ $=\mathrm{G} \hat{E} \mathrm{~F}+\mathrm{O} \hat{E} \mathrm{~F}$. As diagonais de um quadrado dividem o mesmo em dois triângulos retângulos isósceles e congruentes pelo caso LAL. Logo os ângulos agudos destes triângulos medem $45^{\circ}$.

d) Verdadeira, pois ambos tem a mesma inclinação em relação à reta r. No caso, ambos formam ângulo de $45^{\circ}$ com esta reta, visto que são diagonais de quadrados e estas diagonais são bissetrizes dos ângulos internos.

e) Um trapézio é um quadrilátero com dois lados opostos paralelos. Pelo visto no item (d) FDEO é trapézio.

\section{Comentários:}

Classificamos esta atividade para o $9^{\circ}$ ano, visto que é o ano de finalidade do Ensino Fundamental e os alunos já tem um bom ferramental teórico para construírem sua argumentação escrita. Segundo a classificação feita na BNCC, nesta etapa é orientado como Objeto de Conhecimento as Demonstrações de relações entre os ângulos formados por retas paralelas intersectadas por uma transversal que tem como habilidade (EF09MA09) "Demonstrar relações simples entre os ângulos formados por retas paralelas cortadas por uma transversal." [BRASIL, 2018, p.316 e 317]

Essa atividade pressupõe um certo conhecimento, por parte dos alunos, de algumas definições e propriedades de figuras geométricas, como visto nos itens (a) e (e), sendo esperado que os alunos lembrem que um quadrado tem 4 lados de mesma medida, 4 ângulos internos iguais, todos eles retos. Sobre o trapézio, é esperado que saibam que um trapézio tem um par de lados paralelos.

Nos itens (b) e (c) os alunos irão procurar ângulos retos manipulando a Figura 3.6. Na Figura 3.7, temos ressaltados alguns destes ângulos.

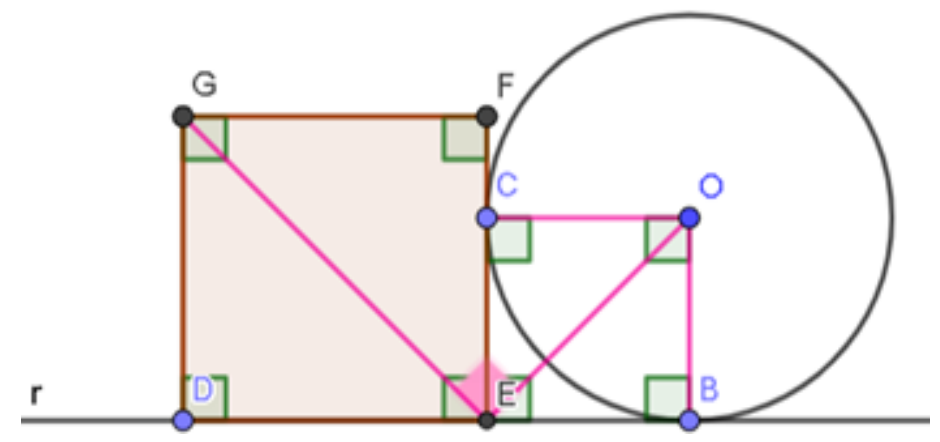

Figura 3.7: Ângulos retos ressaltados

O item (d) prepara o aluno para responder o próximo item, visto que instiga o aluno a comprovar o paralelismo entre os segmentos DF e EO. 
Como visto, esta é uma atividade onde praticamente inexistem cálculos, instigando os alunos a utilizarem sua percepção e conhecimentos previamente adquiridos para resolver as questões que são colocadas. Essa atividade estimula o aluno a verbalizar, debater e posteriormente escrever suas conclusões. O item (c) é uma questão que provavemente irá gerar troca de ideias entre os discentes, pois pode ocorrer que eles encontrem triângulos diferentes, gerando assim colaboração entre os participantes da aula.

\section{5}

\section{Atividade 5: Medidas de tendência central e dispersão}

Tabela 3.5: Descrição da atividade 5

\begin{tabular}{|c|c|c|}
\hline Conteúdo & Ano de Escolaridade & Objetivo \\
\hline $\begin{array}{l}\text { Medidas de tendência } \\
\text { central e de dispersão }\end{array}$ & Ensino Médio & Usar as medidas de tendência central \\
& & e de dispersão para auxiliar \\
na tomada de decisões
\end{tabular}

Imagine que você é diretora ou diretor de um grande clube de futebol. Seu clube está precisando de um atacante e foram oferecidos três atletas. Você deve tomar a decisão de contratar um destes jogadores, baseando-se em algumas estatíticas.

a) A tabela abaixo mostra a média de gols dos jogadores, nos últimos dez jogos em que eles jogaram:

Tabela 3.6: Média de gols

\begin{tabular}{|c|c|}
\hline Jogador & Média de gols por jogo \\
\hline A & 1 \\
\hline B & 0,8 \\
\hline C & 1,2 \\
\hline
\end{tabular}

Estes dados são suficientes para você tomar uma decisão? Se sim, qual foi sua escolha? Se não, quais dados a mais você precisa?

Resposta possível: Preciso de mais dados. Quero saber quantos gols por jogo cada jogador marcou.

b) Após sua equipe fazer uma pesquisa, foram encontrados mais dados sobre estes jogadores, uma tabela contendo o número de gols nos últimos 10 jogos em que eles jogaram: 
Tabela 3.7: Distribuição de gols por jogo nos últimos 10 jogos

\begin{tabular}{|c|c|c|c|c|c|c|c|c|c|c|}
\hline Jogador & Jogo 1 & Jogo 2 & Jogo 3 & Jogo 4 & Jogo 5 & Jogo 6 & Jogo 7 & Jogo 8 & Jogo 9 & Jogo 10 \\
\hline A & 1 & 0 & 2 & 0 & 3 & 0 & 0 & 2 & 2 & 0 \\
\hline B & 1 & 1 & 0 & 1 & 0 & 1 & 1 & 1 & 1 & 1 \\
\hline C & 4 & 2 & 0 & 0 & 0 & 0 & 2 & 2 & 2 & 0 \\
\hline
\end{tabular}

Com estes novos dados em mãos, se você já tomou uma decisão você a mudaria? Se não havia tomado decisão, com estes novos dados você já consegue se decidir? Explique.

Resposta possível: Com estes novos dados eu optaria pelo jogador B pois em quase todo jogo ele faz gol e estamos precisando de um atacante constante em nosso time.

c) Agora você deve justificar sua escolha para os investidores do clube. Prepare um gráfico de barras com os dados da Tabela 3.7, calcule a variância, o desvio padrão e apresente suas conclusões.

\section{Resposta possível:}

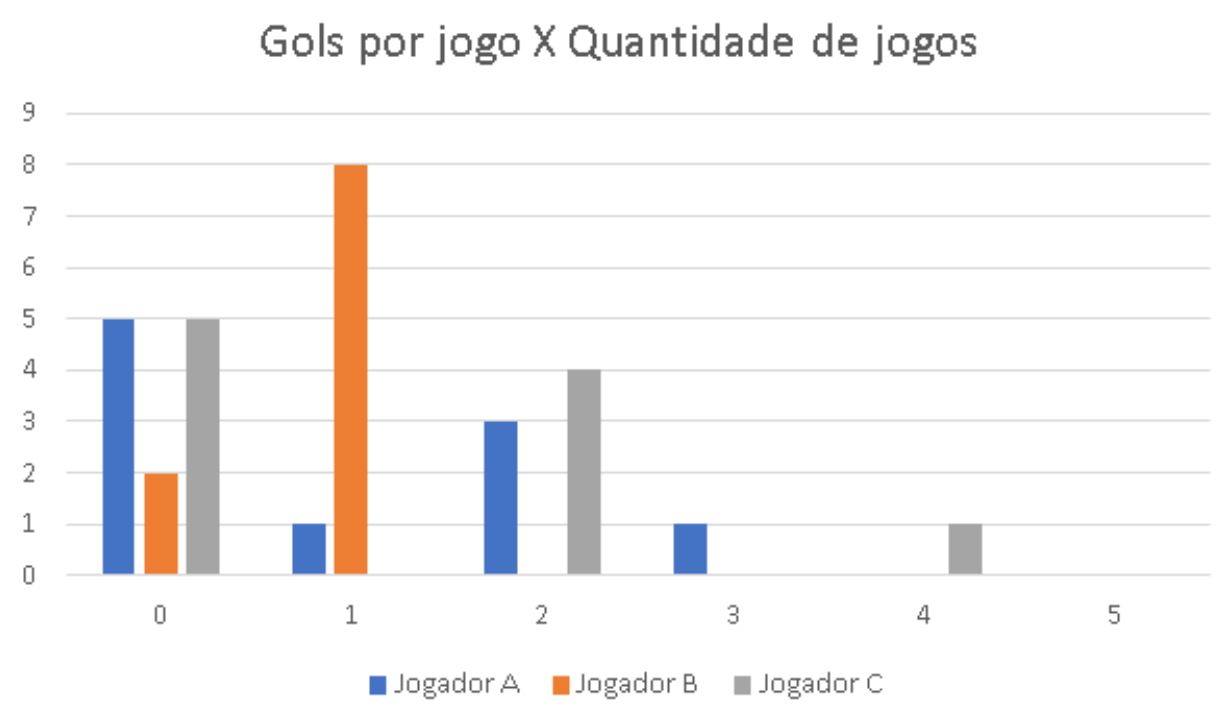

Figura 3.8: Gráfico de barras

Tomando como base o gráfico contido na figura 3.8 vemos que o jogador B só não fez gols em dois dos jogos, diferente dos jogadores $\mathrm{A}$ e $\mathrm{C}$ que passaram em branco em 5 jogos cada um. Mesmo com o B tendo a menor média de gols, a distribuição dos gols dele é mais coesa. Vemos isso pela dispersão dos dados no gráfico e podemos ver tembém numericamente, comparando a variância ou desvio padrão dos três jogadores. 
Tabela 3.8: Tabela com média, variância e desvio padrão

\begin{tabular}{|c|c|c|c|}
\hline Jogador & Média & Variância & Desvio Padrão \\
\hline A & 1 & 1,33 & 1,15 \\
\hline B & 0,8 & 0,18 & 0,42 \\
\hline C & 1,2 & 1,96 & 1,40 \\
\hline
\end{tabular}

\section{Comentários:}

$\mathrm{Na}$ BNCC as habilidades do Ensino Médio não estão classificadas por ano, mas divididas em Competências Específicas. Dentro da Competência Específica 3 temos a habilidade (EM13MAT316):

Resolver e elaborar problemas, em diferentes contextos, que envolvem cálculo e interpretação das medidas de tendência central (média, moda, mediana) e das medidas de dispersão (amplitude, variância e desvio padrão).[BRASIL, 2018, p.537]

Enquadramos esta atividade nesta habilidade.

Por mais que estejam propostas respostas possíveis nas questões, esta atividade tem respostas totalmente abertas podendo gerar uma gama de debates sobre diferentes pontos de vista dos alunos desde a primeira questão. Já de início o debate deve ser incentivado para que cada aluno justifique e compare sua visão com a dos colegas.

$\mathrm{Na}$ segunda questão os alunos são levados a refletir e perceber se os dados mostrados anteriormente estavam escondendo alguma coisa podendo, a partir daí, mudar ou manter seu discurso. Como esta não é uma atividade de resposta fechada, os alunos tendem a se sentir mais confortáveis para realmente expressar o que estão pensando, ao mesmo tempo que estão usando conceitos matemáticos da forma mais natural possível, usando a Língua Portuguesa.

A terceira questão culmina com uma justificativa oral da decisão, auxiliada por meio de um gráfico e das medidas de dispersão que, dependendo da escolha do aluno, podem ser ignoradas, confiando sua decisão a outros aspectos dos jogadores que eles acharam mais interessantes, como o fato de um jogador fazer muitos gols em uma única partida ou ter maior média de gols.

Novamente foram trabalhados conceitos matemáticos, foram feitas algumas contas, porém em um contexto que propiciou aos alunos falar e escrever. 


\section{4}

\section{Fragmentos matemáticos}

Neste capítulo serão apresentadas definições e demonstrações de tópicos que foram abordados nas propostas de atividades do capítulo anterior. Além de dar uma fundamentação teórica a alguns tópicos abordados pretende-se que essa seção contribua com a formação continuada de professores da escola básica interessados em alguns desses temas. As definições e demonstrações aqui apresentadas tiveram por base os livros "Números: Uma Introdução à Matemática"[MILIES \& COELHO, 2006], "Geometria Euclidiana Plana"[BARBOSA, 2006], "Álgebra linear com aplicações"[ANTON \& RORRES, 2012] e o site "Portal da OBMEP"1. As demonstrações dos teoremas e proposições aqui enunciados e não demonstrados, por não fazerem parte do escopo principal do presente trabalho, também podem ser consultadas nas referências acima listadas.

\section{1}

\section{Atividade 1}

Queremos tratar de dois resultados importantes envolvendo números primos. O Teorema Fundamental da Aritmética, que diz que todo número inteiro composto pode ser escrito como produto com fatores primos e essa decomposição se dá de forma única, além de demonstrar que existem infinitos números primos.

Iremos trabalhar dentro do conjunto dos números inteiros, expandindo um pouco do que foi tratado na atividade proposta, onde focamos no conjunto dos números naturais.

Definição 4.1 Dizemos que um inteiro p é primo se p tem exatamente quatro divisores, $1,-1, p e-p$.

Definição 4.2 Seja n um número inteiro diferente de -1, 0 e 1. Se n não for um número primo, dizemos que n é composto.

Proposição 4.3 Se um número primo $p$ divide um produto $a_{1} a_{2} \cdots a_{n}$, então $p \mid a_{k}$, para algum $k, 1 \leq k \leq n$.

${ }^{1}$ https://portaldaobmep.impa.br/index.php 
Teorema 4.4 (Teorema Fundamental da Aritmética) Seja a um inteiro diferente de -1, 0 e 1. Então existem primos positivos $p_{1}<p_{2}<\ldots<p_{r}$ e inteiros positivos $n_{1}<n_{2}<\ldots<n_{r}$ tais que $a=E p_{1}^{n_{1}} \cdot p_{2}^{n_{2}} \cdots p_{r}^{n_{r}}$, em que $E= \pm 1$, conforme a seja positivo ou negativo. Essa decomposição é única, a menos da ordem.

Prova. Vamos iniciar demonstrando que todo inteiro $a>1$ pode ser escrito como um produto de números primos.

Usando o Principio de Indução sobre $a$, temos que:

1. Caso base: Para $a=2$ vale a proposição, visto que 2 é primo.

2. Vamos considerar como hipótese de indução que o resultado seja verdadeiro para todo inteiro $b$, tal que $2 \leq b<a$. Queremos provar que vale para algum inteiro $a$ maior que $b$.

3. Se a é primo a proposição está demonstrada. Considerando o caso em que $a$ não seja primo, temos que $a$ tem algum divisor positivo $b$, tal que $1<b<a$. Então podemos escrever $a=b c$ com $1<c<a$. Pela hipótese de indução $b$ e $c$ podem ser escritos como produto de primos: $b=p_{1} \cdots p_{\mathrm{s}}$ e $c=q_{1} \cdots q_{\mathrm{k}}$.

Logo, fazendo a substituição, temos $a=p_{1} \cdots p_{\mathrm{s}} q_{1} \cdots q_{\mathrm{k}}$ valendo a proposição também para $a$.

Agora vamos demonstrar que essa decomposição é única. Vamos supor que um inteiro $a$ admite mais do que uma decomposição em produto de fatores primos.

Vamos definir como comprimento de uma decomposição o número de fatoresque estão presentes na mesma.

Vamos demonstrar por indução no comprimento de uma decomposição de $a$ :

1. Caso base: vamos considerar uma decomposição de comprimento 1 , com $a=p_{1}$, com $p_{1}$ primo. Suponhamos que exista outra decomposição para $a$. Teremos então $a=p_{1}=q_{1} q_{2} \cdots q_{\mathrm{s}}$, com $q_{1} \leq q_{2} \leq \ldots \leq q_{\mathrm{s}}$ primos positivos. Como $q_{1}$ divide $q_{1} q_{2} \cdots q_{\mathrm{s}}$, também deve dividir $p_{1}$. Como $p_{1}$ é primo, temos que $p_{1}=q_{1}$. Dividindo por $p_{1}$ os dois membros da igualdade $p_{1}=q_{1} q_{2} \cdots q_{\mathrm{s}}$, temos $1=q_{2} \cdots q_{\mathrm{s}}$. Se $s>1$, temos 1 escrito como produto com fatores primos, o que é um absurdo. Logo $s=1 \mathrm{com}$ $p_{1}=q_{1}$.

2. Vamos supor que a proposição vale para todo inteiro que admita uma decomposição de comprimento $k \geq 1$. Iremos provar que sendo $a$ 
um inteiro com decomposição de comprimento $k+1$, também vale a proposição.

3. Se $a$ admite outra decomposição, temos $a=p_{1} \cdots p_{\mathrm{k}+1}=q_{1} \cdots q_{\mathrm{s}}$, com $q_{1} \leq q_{2} \leq \ldots \leq q_{\mathrm{s}}$ todos primos positivos.

Temos que $q_{1} \mid p_{1} \cdots p_{\mathrm{k}+1}$ e pela Proposição $4.3 q_{1} \mid p_{\mathrm{i}}$, para algum $i$, com $1 \leq i \leq k+1$. Como $p_{\mathrm{i}}$ é primo, temos que $q_{1}=p_{\mathrm{i}}$ tendo, em particular, que $q_{1} \geq p_{1}(1)$.

Analogamente, temos que $p_{1} \mid q_{\mathrm{j}}$, para algum $j$, com $1 \leq j \leq s$ e $p_{1} \geq q_{1}(2)$. Utilizando as desigualdades (1) e (2) temos que $p_{1}=q_{1}$. Dividindo por $p_{1}$ ambos os membros da igualdade $p_{1} \cdots p_{\mathrm{k}+1}=q_{1} \cdots q_{\mathrm{s}}$, temos $p_{2} \cdots p_{\mathrm{k}+1}=q_{2} \cdots q_{\mathrm{s}}$. Então o primeiro membro da igualdade tem $k$ fatores e, pela hipótese de indução, sua decomposição é única. Temos então que $k=s-1$, adicionando 1 aos membros desta igualdade obtemos $k+1=s, \operatorname{com} p_{\mathrm{i}}=q_{\mathrm{i}}$, para $i=2, \ldots, k+1$. Já provamos que $p_{1}=q_{1}$, logo as expressões coincidem em todos os seus fatores, tendo o mesmo comprimento.

Generalizando, de acordo com enunciado proposto, tomemos $a=E|a|$ com $E=1$ ou $E=-1$, dependendo de $a$ ser positivo ou negativo. Como $|a|$ é positivo temos, do que provamos anteriormente, que existem primos $p_{1} \leq p_{2} \leq \ldots \leq p_{\mathrm{t}}$ tais que $a=E p_{1} \leq p_{2} \leq \ldots \leq p_{\mathrm{t}}$.

Se houver primos repetidos, podemos agrupá-los, escrevendo em forma de potência: $a=E p_{1}{ }^{\mathrm{n}_{1}} \cdot p_{2}{ }^{\mathrm{n}_{2}} \cdots p_{\mathrm{r}}{ }^{\mathrm{n}_{\mathrm{r}}}$, tendo a unicidade já demonstrada anteriormente.

Teorema 4.5 O conjunto dos números primos é infinito.

Prova. Suponhamos que existam n números primos. Podemos colocá-los dispostos em uma sequência crescente: $p_{1}, p_{2}, \ldots, p_{\mathrm{n}}$.

Vamos considerar o número $P=p_{1} p_{2} \cdots p_{\mathrm{n}}+1$. Como $p_{\mathrm{n}}$ é o maior número primo e $P>p_{\mathrm{n}}$, temos que $P$ não é primo. Pelo Teorema Fundamental da Aritmética, sabemos que $\mathrm{P}$ admite um divisor positivo primo $p_{\mathrm{i}}$. Mas $p_{\mathrm{i}}$ deve ser um dos elementos da sequência acima, sendo então $p_{\mathrm{i}}$ divisor de $p_{1} p_{2} \cdots p_{\mathrm{n}}$ e também divisor de $P$. Logo $p_{1}$ deve dividir $P-p_{1} p_{2} \cdots p_{\mathrm{n}}=1$, o que é uma contradição, pois 1 só tem como divisor positivo o próprio 1 . Logo $P$ é um primo maior que $p_{\mathrm{n}}$. 


\section{2}

\section{Atividade 2}

Iremos definir alguns conceitos e demonstrar alguns resultados vistos na segunda atividade, dando um olhar mais formal ao que foi ali proposto. Todos as definições e resultados estão no universo da Geometria Euclidiana Plana.

Munidos das definições de distância de ponto a ponto e de distância de ponto a reta, iremos enunciar e demonstrar dois resultados que juntos mostram que dados uma reta e um ponto não pertencente a esta reta, o segmento que é definido como distância entre o ponto e a reta é único e o menor entre todos os segmentos que ligam o ponto à reta.

Também iremos demonstrar a proposição vista na parte 2 da atividade que diz que dados um círculo de centro $\mathrm{O}$ e a reta tangente ao círculo em um ponto $\mathrm{B}$, esta reta é perpendicular ao raio $\mathrm{OB}$.

Axioma 1 Dados dois pontos distintos existe uma única reta que os contém.

Definição 4.6 Sejam dois pontos $A$ e $B$ no plano e $r$ a reta que passa por $A$ e $B$. Definimos como distância entre $A$ e $B$ a medida do segmento $A B$.

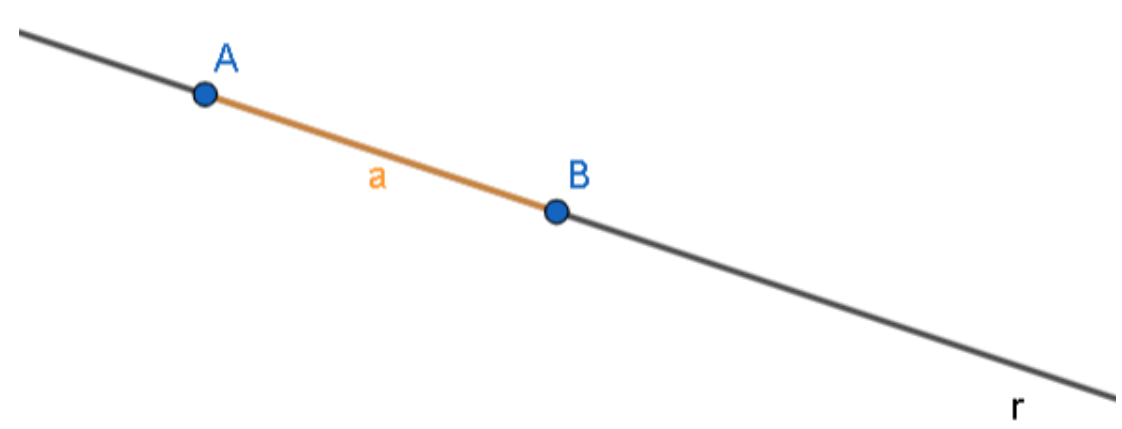

Figura 4.1: Medida do segmento AB

Definição 4.7 Seja $A$ um ponto e $r$ uma reta, tais que $A \notin r$. Seja s uma reta perpendicular à $r$, de forma que $A \in s$. Denotando por $B=r \cap s$. Definimos a distância entre $A$ e $r$ como a medida do segmento $A B$. 


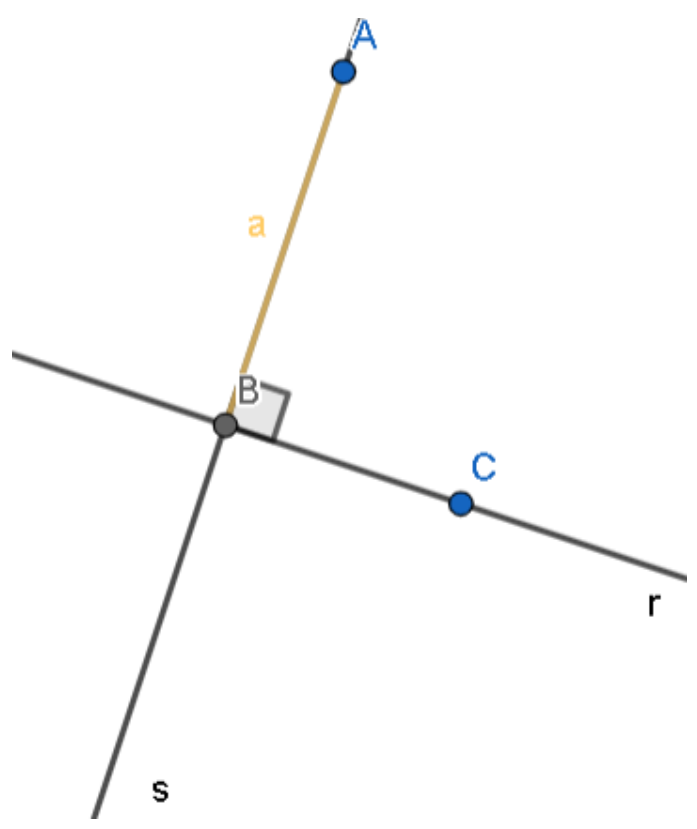

Figura 4.2: Distância do ponto $\mathrm{A}$ à reta $\mathrm{r}$

Teorema 4.8 Dados uma reta $r$ e um ponto $A \notin r$ existe somente um segmento perpendicular à reta $r$ que liga o ponto $A$ à reta $r$.

Prova. Seja B um ponto tal que $B \in \mathrm{r}$ e que $\mathrm{AB}$ é um segmento perpendicular à reta $\mathrm{r}$. Suponhamos que exista um ponto $\mathrm{C}$, distinto de $\mathrm{B}$, tal que $\mathrm{C} \in \mathrm{r}$ e AC também é perpendicular à r. Como A, B e C são pontos distintos e, por construção, não colineares, podemos formar o triângulo $\mathrm{ABC}$, o que é um absurdo, visto que $\mathrm{A} \hat{B} \mathrm{C}$ e $\mathrm{B} \hat{C} \mathrm{~A}$ são retos, logo a soma dos ângulos internos do triângulo $\mathrm{ABC}$ é maior que um ângulo raso. Assim $\mathrm{AB}$ é o único segmento partindo do ponto $\mathrm{A}$ que é perpendicular à reta $\mathrm{r}$.

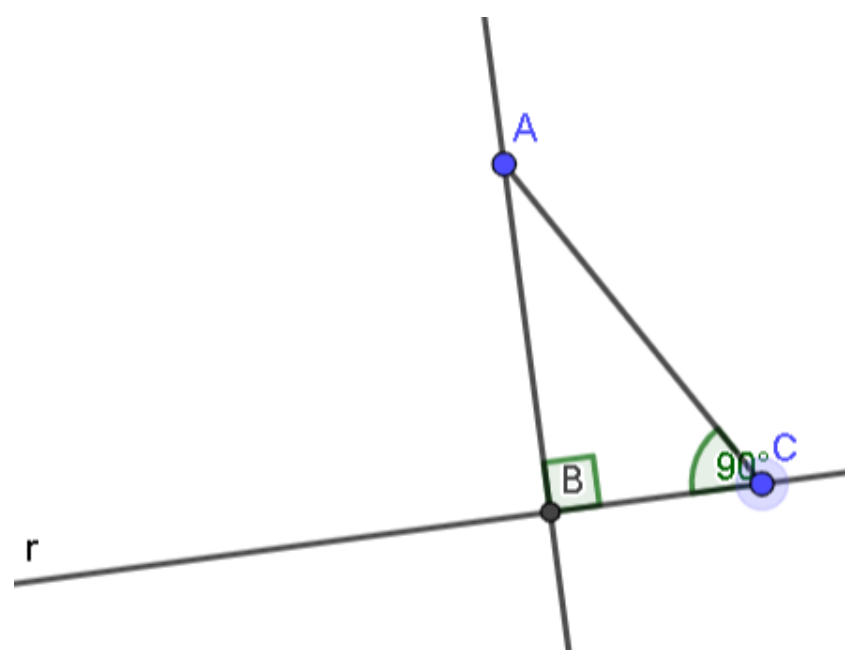

Figura 4.3: Triângulo ABC com dois ângulos retos 
Teorema 4.9 Dados uma reta $r$ e um ponto $A \notin r$, o menor segmento que liga o ponto $A$ à reta $r$ é o segmento que é perpendicular à reta $r$.

Prova. Existem infinitos segmentos ligando o ponto A à reta r. Seja AB o segmento perpendicular à reta $\mathrm{r}, \mathrm{com} \mathrm{B} \in \mathrm{r}$.

Seja $\mathrm{C} \neq \mathrm{B}$, com $\mathrm{C} \in \mathrm{r}$. Podemos formar o triângulo retângulo $\mathrm{ABC}$, reto no vértice $\mathrm{B}$. Como em um triângulo, o maior lado está oposto ao maior ângulo, temos que $\mathrm{AB}$ é menor que $\mathrm{AC}$, pois $\mathrm{AC}$ está oposto ao ângulo $\mathrm{A} \hat{B} \mathrm{C}$ que é reto. Independente da escolha de $\mathrm{C}$, sempre $\mathrm{AB}$ será menor que $\mathrm{AC}$. Logo $\mathrm{AB}$ é o menor segmento que liga o ponto A à reta $\mathrm{r}$.

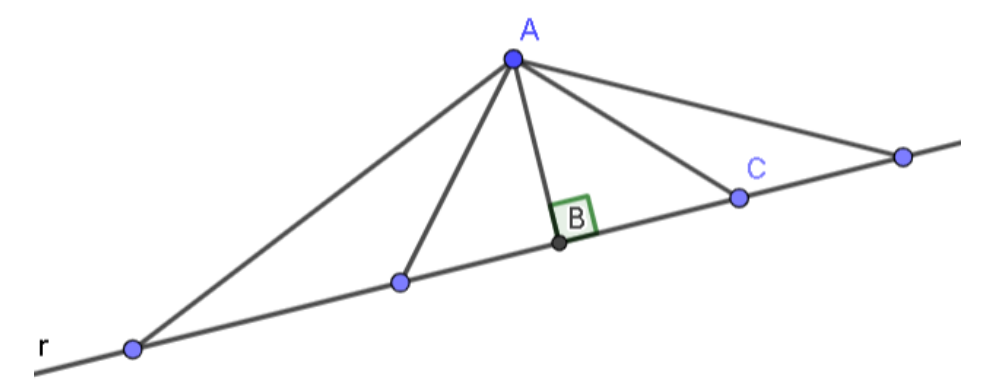

Figura 4.4: Segmentos que ligam o ponto $\mathrm{A}$ à reta $\mathrm{r}$

Definição 4.10 Dizemos que um círculo denotado por $C$ é tangente a uma reta $r$ se existe somente um ponto em comum entre $C$ e $r$. Designando tal ponto por $T$, dizemos que $r$ é tangente à $C$ no ponto $T$.

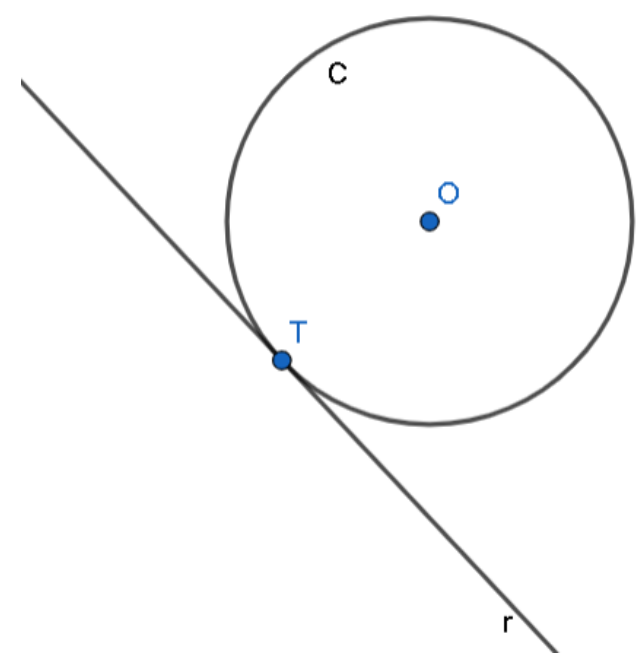

Figura 4.5: reta $\mathrm{r}$ tangente ao círculo $\mathrm{C}$ no ponto $\mathrm{T}$

Definição 4.11 Dizemos que dois triângulos $A B C$ e EFG são congruentes se ocorre, para alguma nomeação dos vértices dos triângulos, uma organização tal que:

$$
\hat{\mathrm{A}}=\hat{\mathrm{E}}, \hat{B}=\hat{F}, \hat{C}=\hat{G}, A B=E F, B C=F G \text { e } C A=G E .
$$


Definição 4.12 Seja um ponto $A$ e um círculo de centro $O$ e raio $r$. Temos três posições relativas entre o círculo e o ponto $A$. Se a distância entre $A$ e $O$ for menor que $r$, o ponto $A$ é interno ao círculo. Se a distância entre $A$ e $O$ for igual à $r$, o ponto A pertence ao círculo. Se a distância entre $A$ e $O$ for maior que $r$, o ponto $A$ é exterior ao círculo.

Proposição 4.13 Se uma reta é tangente a um círculo então ela é perpendicular ao raio que liga o centro ao ponto de tangencia.

Prova. Seja um círculo de centro $\mathrm{O}$ e uma reta $\mathrm{r}$ tangente ao círculo no ponto T. Denotemos por $\mathrm{P}$ o pé do segmento perpendicular que liga o ponto $\mathrm{O}$ à reta r. Queremos demonstrar que P e T coincidem.

Admitindo que $\mathrm{P}$ e $\mathrm{T}$ são distintos pode formar-se o triângulo OPT, retângulo em $\mathrm{P}$, temos que OT é a hipotenusa deste triângulo retângulo, sendo então OT o maior dos lados deste triângulo. Mas, por construção OT é raio do círculo de centro O. Sendo $\mathrm{OP}<\mathrm{OT}$, temos que OP tem medida menor que o raio do círculo e, consequentemente, $\mathrm{P}$ deve ser um ponto interno ao círculo de centro O. Isto significa que r não é tangente. Contradição. Está provado.

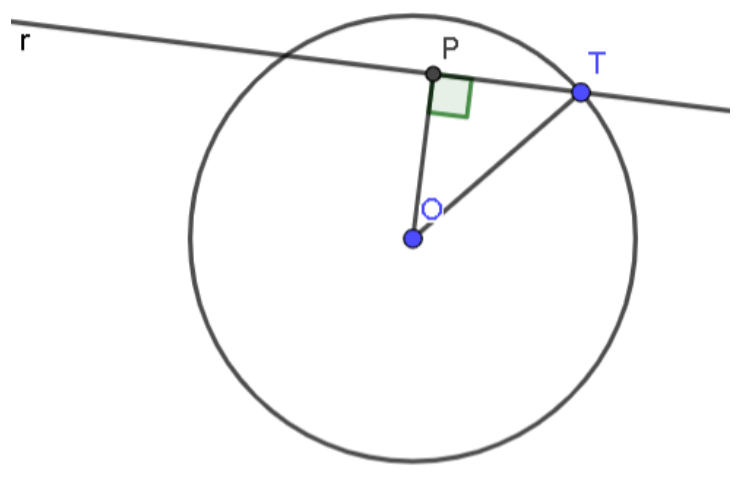

Figura 4.6: Triângulo retângulo OPT e reta $\mathrm{r}$ secante ao círculo

\section{3}

\section{Atividade 3}

Nesta atividade falamos sobre equações lineares. Vamos agora apresentar a definição de sistemas de equações lineares e demonstrar que equações lineares com duas incógnitas podem ser representadas por retas no plano, assim como demonstrar que toda reta no plano pode ter seus pontos descritos por uma equação linear com duas incógnitas. Para tal, iremos verificar qual a condição para que três pontos sejam colineares em um plano. 
Definição 4.14 Podemos escrever um sistema de equações lineares com $m$ equações nas $n$ incógnitas $x_{1}, x_{2}, \ldots, x_{n}$, de forma arbitrária, assim:

$$
\left\{\begin{array}{c}
a_{11} x_{1}+a_{12} x_{2}+\ldots+a_{1 n} x_{n}=b_{1} \\
a_{21} x_{1}+a_{22} x_{2}+\ldots+a_{2 n} x_{n}=b_{2} \\
\ldots \\
a_{m 1} x_{1}+a_{m 2} x_{2}+\ldots+a_{m n} x_{n}=b_{m}
\end{array}\right.
$$

Sendo $a_{m, n}$ e $b_{m}$ números reais com $m, n \in \mathbb{N}$.

No nosso caso, vamos focar nos sistemas de equações com duas equações e duas incógnitas.

Definição 4.15 Dizemos que dois triângulos $A B C$ e EFG são semelhantes se ocorre, para alguma nomeação dos vértices dos triângulos, uma organização tal que:

$$
\hat{\mathrm{A}}=\hat{\mathrm{E}}, \hat{B}=\hat{F}, \hat{C}=\hat{G} e \frac{A B}{E F}=\frac{B C}{F G}=\frac{C A}{G E} .
$$

Teorema 4.16 (Caso AA de semelhança de triângulos) Dados dois triângulos $A B C$ e EFG, se $\hat{\mathrm{A}}=\hat{\mathrm{E}}$ e $\hat{B}=\hat{F}$ então os triângulos são semelhantes.

Teorema 4.17 (Caso LAL de semelhança de triângulos) Dados dois triângulos $A B C$ e EFG, se $\hat{\mathrm{A}}=\hat{\mathrm{E}}$ e $\frac{A B}{E F}=\frac{A C}{E G}$ então os trîangulos são semelhantes.

\section{Condição de colinearidade entre três pontos no plano:}

Consideremos três ponto A, B e C no plano cartesiano, de tal forma que $A=\left(x_{1}, y_{1}\right), B=\left(x_{2}, y_{2}\right), C=\left(x_{3}, y_{3}\right)$. Vamos supor que estes três pontos sejam colineares.

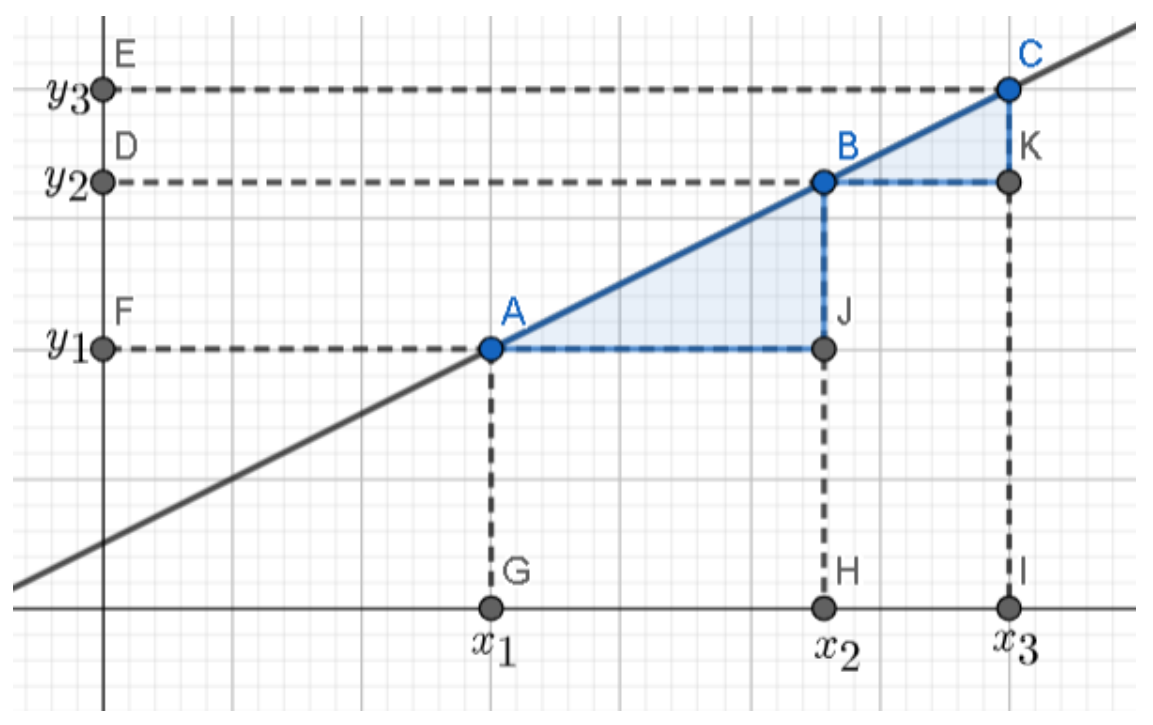

Figura 4.7: Pontos A, B e C colineares 
Ao formar os triângulos AJB e BKC, como na figura 4.7, podemos verificar que eles são semelhantes pelo caso AA de semelhança de triângulos, pois os ângulos AJB e BKC são retos e os ângulos BAJ e CBK são congruentes visto que as retas DK e FJ são paralelas cortadas pela transversal AB. Daí temos que: $\frac{A J}{B K}=\frac{J B}{K C}$. Escrevendo em coordenadas, temos: $\frac{x_{2}-x_{1}}{x_{3}-x_{2}}=\frac{y_{2}-y_{1}}{y_{3}-y_{2}}$, $\Longleftrightarrow\left(x_{2}-x_{1}\right) \cdot\left(y_{3}-y_{2}\right)=\left(x_{3}-x_{2}\right) \cdot\left(y_{2}-y_{1}\right) \Longleftrightarrow\left(x_{2}-x_{1}\right) \cdot\left(y_{3}-y_{2}\right)-\left(x_{3}-\right.$ $\left.x_{2}\right) \cdot\left(y_{2}-y_{1}\right)=0 \Longleftrightarrow x_{1} \cdot y_{2}+x_{2} \cdot y_{3}+x_{3} \cdot y_{1}-x_{2} \cdot y_{1}-x_{3} \cdot y_{2}-x_{1} \cdot y_{3}=0$ (1). Ao substituir o valor das coordenadas de três pontos na equação (1), ficando válida a equação, teremos que os pontos são colineares.

Proposição 4.18 Qualquer reta no plano cartesiano pode ser representada por uma equação do tipo: $a x+b y=c$, com $a^{2}+b^{2} \neq 0$.

Prova. Pelo Axioma 1, sabemos que dados dois pontos A e B distintos, existe somente uma reta que passa por estes dois pontos. Digamos que $A=\left(x_{1}, y_{1}\right)$, $B=\left(x_{2}, y_{2}\right)$ e r uma reta que passa por $\mathrm{A}$ e $\mathrm{B}$. Um ponto qualquer $C=(x, y)$ está contido em $\mathrm{r}$, se é colinear com $\mathrm{A}$ e $\mathrm{B}$. Logo para $\mathrm{C}$ pertencer à reta, deve ser satisfeito: $x_{1} \cdot y_{2}+x_{2} \cdot y+x \cdot y_{1}-x_{2} \cdot y_{1}-x \cdot y_{2}-x_{1} \cdot y=0 \Longleftrightarrow\left(\mathrm{y}_{1}-\mathrm{y}_{2}\right) \mathrm{x}+\left(\mathrm{x}_{2}{ }^{-}\right.$ $\left.\mathrm{x}_{1}\right) \mathrm{y}+\left(\mathrm{x}_{1} \cdot y_{2}-x_{2} \cdot y_{1}\right)=0$. Como $x_{1}, x_{2}, y_{1}$ e $y_{2}$ são dados, podemos fazer as seguintes substituições:

$a=y_{1}-y_{2}$

$b=x_{2}-x_{1}$

$c=x_{1} \cdot y_{2}-x_{2} \cdot y_{1}$

Daí teremos, $a x+b y=c$. Denotaremos esta equação por equação geral da reta.

Podemos também demonstrar a recíproca desta proposição.

Proposição 4.19 Toda equação do tipo $a x+b y=c$, com $a^{2}+b^{2} \neq 0$, representa uma reta no plano cartesiano.

Prova. Queremos demonstrar que dados os pontos formados pela equação $a x+b y=c$ estão todos alinhados.

Como $a^{2}+b^{2} \neq 0$, vamos analisar o caso em que $a=0$ ou $b=0$. Suponhamos $b=0$. Temos uma equação da forma $a x=c$. Logo $x=\frac{c}{a}$ que é constante, estando então todos os pontos alinhados.

Agora para $a$ e $b$ diferentes de zero, sendo $\left(x_{1},\left(\frac{c-a x_{1}}{b}\right)\right),\left(x_{2},\left(\frac{c-a x_{2}}{b}\right)\right)$ e $\left(x,\left(\frac{c-a x}{b}\right)\right)$ três pontos arbitrários que satisfazem a equação dada temos, pela condição de colinearidade, que estes pontos estão alinhados, visto que $\frac{\left(x_{2}-x_{1}\right) b}{c-a x_{1}-c+a x_{2}}=\frac{\left(x_{2}-x\right) b}{c-a x_{2}-c+a x}$, simplificando ambos os membros desta equação, temos que $\frac{b}{a}=\frac{b}{a}$. Da arbitrariedade dos pontos escolhidos resulta que o conjunto de pontos representado por aquela equação é uma reta. 
Com estes resultados em mãos temos uma interpretação geométrica para sistemas lineares de duas equações e duas incógnitas, baseando-se nas posições relativas entre duas retas. Quando um sistema é do tipo $\left\{\begin{array}{l}a_{1} x+b_{1} y=c_{1} \\ a_{2} x+b_{2} y=c_{2}\end{array}\right.$ sabemos que cada uma das equações gera uma reta no plano cartesiano, sendo que estas retas podem:

1. ser estritamente paralelas, não tendo nenhum ponto em comum. Desse modo, não existe nenhum par ordenado $(x, y)$ que satisfaça as duas equações ao mesmo tempo, fazendo com que não exista solução para o sistema. Teremos esta situação quando as equações geram duas retas que tem a mesma inclinação em relação ao eixo x, porém uma é uma translação da outra.

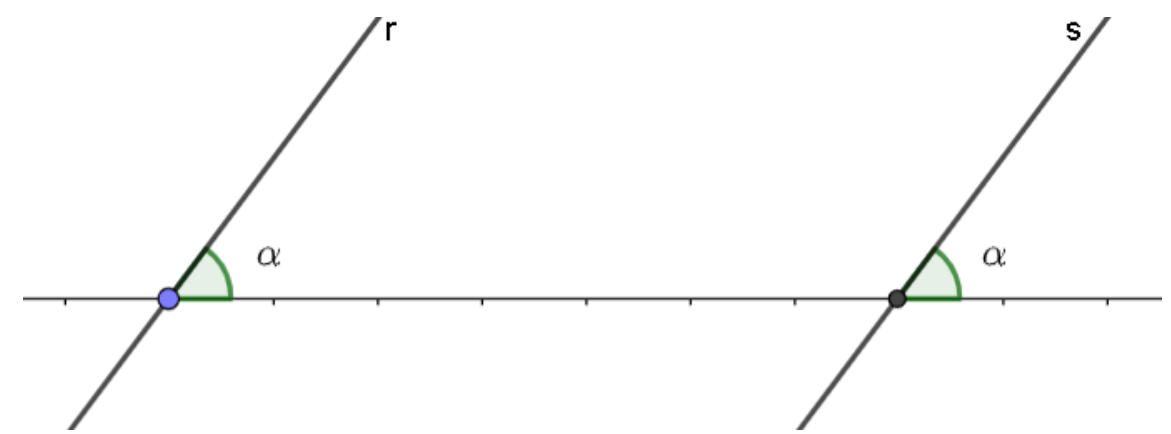

Figura 4.8: Retas r e s paralelas

Observando de forma algébrica, ocorre: $\left\{\begin{array}{l}a_{1} x+b_{1} y=c_{1} \\ a_{2} x+b_{2} y=c_{2}\end{array}\right.$, com $a_{1} b_{2}-$ $a_{2} b_{1}=0$ e $a_{1} c_{2}-a_{2} c_{1} \neq 0$.

2. ser concorrentes em um ponto $A=(x, y)$. Isto quer dizer que existe um par ordenado $(x, y)$ que satisfaz as duas equações simultaâneamente, fazendo com que exista uma única solução para o sistema.

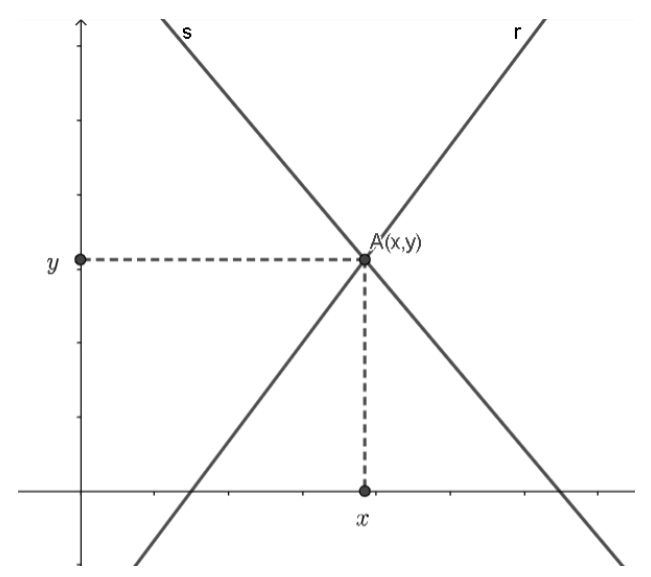

Figura 4.9: Retas r e s concorrente no ponto A 
Algebricamente temos: $\left\{\begin{array}{l}a_{1} x+b_{1} y=c_{1} \\ a_{2} x+b_{2} y=c_{2}\end{array}\right.$, com $a_{1} b_{2}-a_{2} b_{1} \neq 0$.

3. ser sobrepostas, ou seja, existem infintos pares ordenados $(x, y)$ que satisfazem as duas equações, fazendo com que existam infinitas soluções para o sistema.

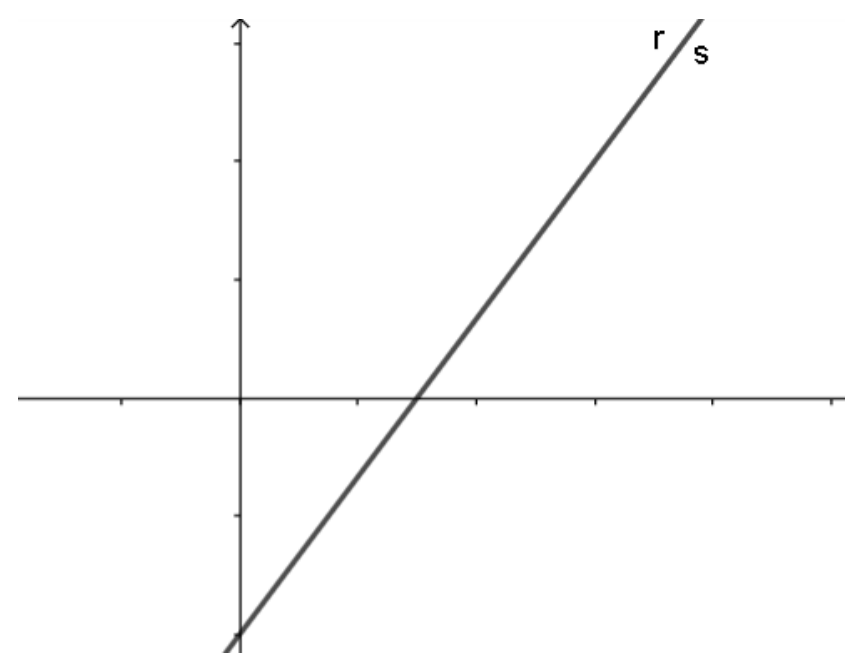

Figura 4.10: Retas r e s sobrepostas

Devemos ter no sistema: $\left\{\begin{array}{l}a_{1} x+b_{1} y=c_{1} \\ a_{2} x+b_{2} y=c_{2}\end{array} \quad\right.$, com $a_{1} b_{2}-a_{2} b_{1}=0$ e $a_{1} c_{2}-a_{2} c_{1}=0$.

\section{4}

\section{Atividade 4}

De acordo com os assuntos abordados na atividade 4, queremos trazer algumas definições e resultados envolvendo quadriláteros, circunferências e algumas relações entre eles.

Teorema 4.20 Ângulos opostos pelo vértice são congruentes.

Teorema 4.21 Sejam duas retas $f$ e $g$ e uma reta $h$ transversal às duas primeiras. $f$ e g são paralelas se, e somente se, os ângulos correspondentes são congruentes.

De acordo com os teoremas 4.20 e 4.21, temos que os ângulos marcados com a mesma cor, na figura abaixo, são congruentes, sendo f e g retas paralelas e h transversal às duas. 


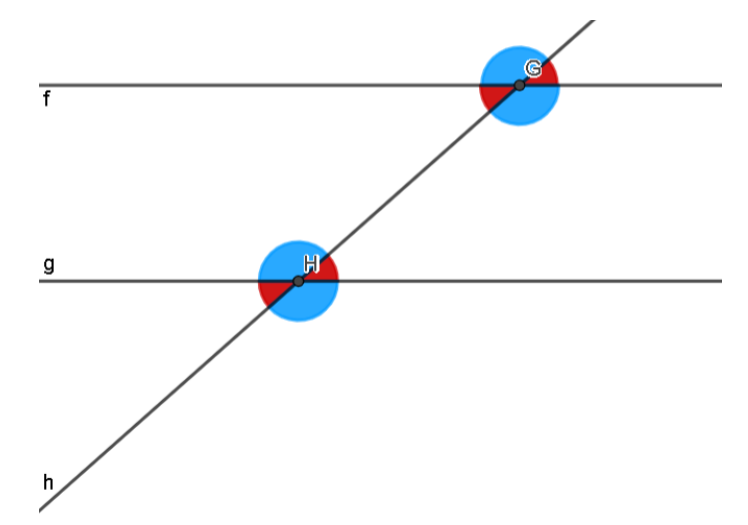

Figura 4.11: Reta h transversal às paralelas $\mathrm{f}$ e $\mathrm{g}$

Axioma 2 (Caso LAL de congruência de triângulos) Dados dois triângulos $A B C$ e $E F G$, se $A B=E F, A C=E G$ e $\hat{A}=\hat{E}$ então $A B C$ é congruente a $E F G$.

É importante ressaltar que dos três casos de congruência de triângulos na geometria plana, sempre um deles é considerado Axioma, servindo de base para demonstrar os demais.

Teorema 4.22 (Caso ALA de congruência de triângulos) Dados dois triângulos $A B C$ e $E F G$, se $\hat{\mathrm{A}}=\hat{\mathrm{E}}, \hat{B}=\hat{F}$ e $A B=E F$ então os triângulos são congruentes.

Proposição 4.23 Em triângulos congruentes ângulos congruentes se opõem à lados congruentes.

Definição 4.24 (Paralelogramo) Denotamos por paralelogramo, todo quadrilátero que tem dois pares de lados opostos paralelos.

Proposição 4.25 Os lados opostos de um paralelogramo são congruentes.

Prova. Seja ABCD um paralelogramo. Tracemos a diagonal AC. Sabemos, pelos teoremas 4.20 e 4.21, que os ângulos $D \hat{A} C$ e $B \hat{A} C$ são respectivamente congruentes aos ângulos $B \hat{C} A$ e $D \hat{C} A$. Então temos que os triângulos $\mathrm{ABC}$ e ADC são congruentes pelo caso ALA de congruência de triângulos, visto que $\mathrm{AC}$ é lado comum aos dois triângulos. Logo, pela Proposição 4.23, os lados AB e $\mathrm{BC}$ são respectivamente congruentes aos lados $\mathrm{CD}$ e $\mathrm{AD}$. 


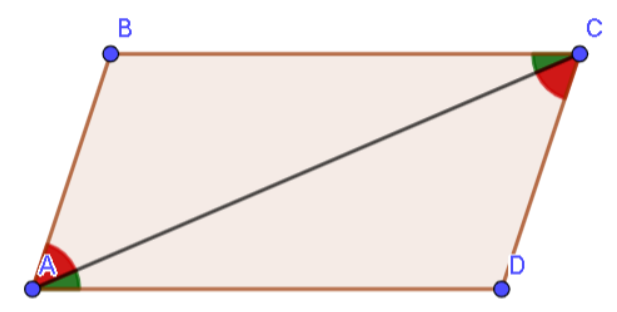

Figura 4.12: Paralelogramo ABCD

Proposição 4.26 O ponto de interseção entre as diagonais de um paralelogramo é ponto médio das mesmas.

Prova. Seja ABCD um paralelogramo. Tomemos as diagonais AC e BD, denotando por E o ponto de interseção entre elas. Pelos teoremas 4.20 e 4.21, os ângulos $C \hat{A} D$ e $B \hat{D} A$ são respectivamente congruentes aos ângulos $A \hat{C} B$ e $D \hat{B} C$ e, além disso, os lados $\mathrm{AD}$ e $\mathrm{BC}$ são congruentes, como foi visto na proposição anterior. Logo os triângulos AED e CEB são congruentes pelo caso ALA de congruência de triângulos. Logo, pela Proposição 4.23, $A E=C E$ e $B E=D E$, sendo assim E o ponto médio de $\mathrm{AC}$ e BD.

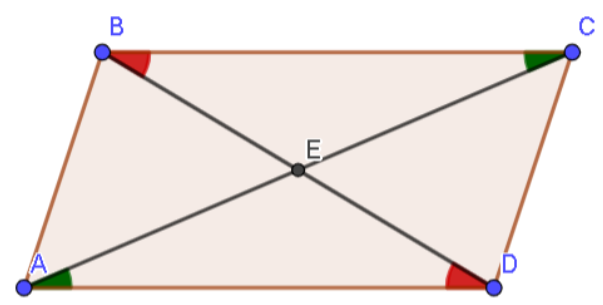

Figura 4.13: Paralelogramo ABCD e suas diagonais AC e BD

Definição 4.27 (Retângulo) Denotamos por retângulo, todo quadrilátero que tem os ângulos internos retos.

Teorema 4.28 A soma da medida dos ângulos internos de um triângulo é $180^{\circ}$.

Proposição 4.29 O retângulo é um paralelogramo.

Prova. Seja ABCD um retângulo. Suponhamos que as semirretas AD e BC não sejam paralelas e se interceptam em um ponto E. Temos formado o triângulo ABE, porém este triângulo tem dois ângulos retos, o que é um absurdo de 
acordo com o teorema 4.28. Logo as semirretas AD e BC são paralelas e consequentemente os lado AD e BC também o são. Analogamente, temos que os lados AB e DC são paralelos. Então o retângulo ABCD é paralelogramo.

Vimos acima que um retângulo é também paralelogramo. Podemos dizer que um retângulo é um paralelogramo cujos ângulos internos são retos. Com isto o retângulo herda as propriedades vistas para paralelogramos, ou seja, dado um retângulo $\mathrm{ABCD}$, seus lados oposto são congruentes e o ponto de intercesão entre suas diagonais é o ponto médio das mesmas, sendo que no retângulo as diagonais são congruentes, como iremos enunciar e demonstrar na sequência.

Proposição 4.30 As diagonais de um retângulo são congruentes.

Prova. Seja ABCD um retângulo com $\mathrm{AC}$ e $\mathrm{BD}$ diagonais deste retângulo. Como $A B=C D, B \hat{A} D=C \hat{D} A=90^{\circ}$ e $\mathrm{AD}$ é lado comum, temos que os triângulos $B A D$ e $C D A$ são congruentes pelo caso LAL de congruência de triângulos. Logo $A C=B D$.

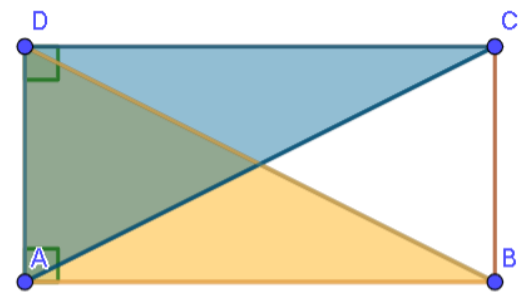

Figura 4.14: Triângulos BAD e CDA congruentes

Definição 4.31 (Losango) Denotamos por losango todo o quadrilátero que tem todos os lados congruentes.

Definição 4.32 (Triângulo isoscéles) Seja ABC um triângulo. Denotamos $A B C$ por isósceles se existem dois lados congruentes, digamos $A B=B C$. Dizemos também que $A C$ é base deste triângulo.

Teorema 4.33 Os ângulos da base, em um triângulo isósceles, são congruentes.

Teorema 4.34 (Caso LLL de congruência de triângulos) Dados dois triângulos $A B C$ e EFG, se $A B=E F, B C=F G$ e $A C=E G$ então os triângulos são congruentes. 
Proposição 4.35 O losango é paralelogramo.

Prova. Seja ABCD um losango. Tracemos a diagonal AC. Temos, pelo caso LLL de congruência de triângulos, que $\mathrm{ABC}$ e $\mathrm{ADC}$ são congruentes. Como $\mathrm{ABC}$ e ADC são isósceles, temos $B \hat{A} C=D \hat{A} C=B \hat{C} A=D \hat{C} A$. Sendo assim os lados $\mathrm{AB}$ e $\mathrm{AD}$ são respectivamente paralelos aos lados $\mathrm{CD}$ e $\mathrm{BC}$, por consequência do teorema 4.21. Logo ABCD é paralelogramo.

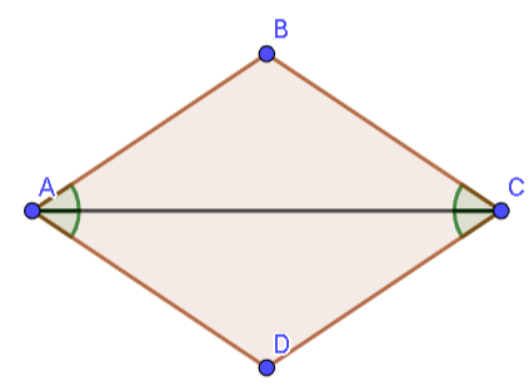

Figura 4.15: Losango ABCD

Tendo em vista o que foi tratado na proposição anterior temos que, assim como o retângulo, o losango herda as propriedades do paralelogramo. Mas, além de suas diagonais se cortarem no ponto médio, elas formam entre si ângulos retos.

Proposição 4.36 As diagonais de um losango formam, entre si, ângulos retos.

Prova. Seja ABCD um losango. Denotando por E o ponto de interseção entre as diagonais $\mathrm{AC}$ e $\mathrm{BD}$ temos que os triângulos $\mathrm{AEB}$, BEC, CED e AED são todos congruentes, visto que os lados $\mathrm{AB}, \mathrm{BC}, \mathrm{CD}$ e $\mathrm{AD}$ tem a mesma medida, pela definição de losango, e os lados $\mathrm{AE}$ e BE são respectivamente congruentes aos lados CE e DE, pelo fato de que as diagonais se cortam no ponto médio. Daí temos que $A \hat{E} B=B \hat{E} C=C \hat{E} D=A \hat{E} D$, com todos estes ângulos formando juntos $360^{\circ}$. Então cada um deles deve medir $90 .^{\circ}$

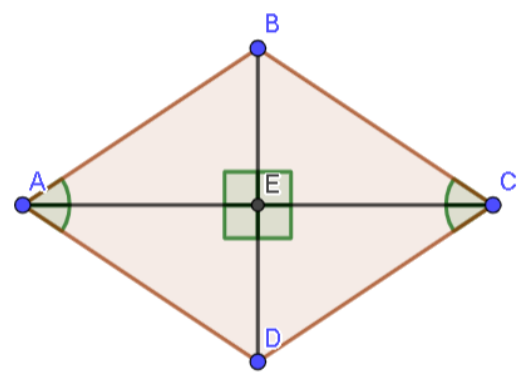

Figura 4.16: Diagonais AC e BD formando ângulos retos 
Definição 4.37 (Quadrado) Denotamos por quadrado todo quadrilátero que tem todos os lados congruentes e ângulos internos retos.

Perceba que poderíamos definir o quadrado como um quadrilátero que é retângulo e losango simultaneamente, fazendo com que este quadrilátero tenha as propriedades tanto do retângulo quanto do losango. Logo o quadrado tem diagonais congruentes que formam entre si ângulos retos.

Definição 4.38 (Trapézio) Denotamos por trapézio todo quadrilátero que contém um par de lados opostos paralelos. Denotamos os lados paralelos por bases do trapézio.

Teorema 4.39 (Teorema de Tales) Seja um feixe de retas paralelas cortadas por duas retas transversais. Os segmentos de reta determinados sobre uma são proporcionais aos segmentos de reta correspondentes determinados sobre a outra se, e somente se, as retas que compõem o feixe são todas paralelas.

Definição 4.40 Seja $A B C$ um triângulo e os pontos $M$ e $N$ são, respectivamente, os pontos médios de $A B$ e BC. Denotamos o segmento $M N$ por base média de $A B C$ em relação ao lado $A C$.

Teorema 4.41 Seja ABC um triângulo e $M N$ base média deste triângulo em relação ao lado $A C$. Temos que $M N$ é paralelo a $A C$ e que $M N=\frac{A C}{2}$.

Definição 4.42 Seja $A B C D$ um trapézio, com bases $A D$ e BC. Sejam $M$ e $N$ os pontos médios de $A B$ e $C D$, respectivamente. Dizemos que $M N$ é base média do trapézio $A B C D$.

Proposição 4.43 Seja $A B C D$ um trapézio e $M N$ sua base média. Sendo $A D$ e $B C$ paralelos, temos que $M N$ é paralelo às bases e $M N=\frac{A D+B C}{2}$.

Prova. Tracemos o segmento MN. Temos, pelo teorema de Tales, que MN é paralelo aos segmentos $\mathrm{AD}$ e $\mathrm{BC}$, visto que $\frac{A M}{B M}=\frac{D N}{C N}=1$ pois $\mathrm{M}$ e $\mathrm{N}$ são, respectivamente, pontos médios de $\mathrm{AB}$ e $\mathrm{CD}$.

Agora vamos traçar as semirretas $\mathrm{BN}$ e $\mathrm{AB}$ denotando por $\mathrm{E}$ o ponto de interseção entre elas. Temos, pelos teoremas 4.20 e 4.21, que os ângulos $E \hat{D} C$ e $N \hat{C} B$ são congruentes, assim como os ângulos $B \hat{N} C$ e $E \hat{N} D$ que são congruentes por serem opostos pelo vértice. Como $\mathrm{CN}=\mathrm{ND}$, os triângulos NDE e NCB são congruentes pelo caso ALA de congruência de triângulos. Logo $D E=B C$. Como $\mathrm{N}$ também é ponto médio de DE temos, pelo teorema 
4.40, que $M N=\frac{A E}{2}$. Sabendo que $A E=A D+D E=A D+B C$, concluímos que $M N=\frac{A D+B C}{2}$.

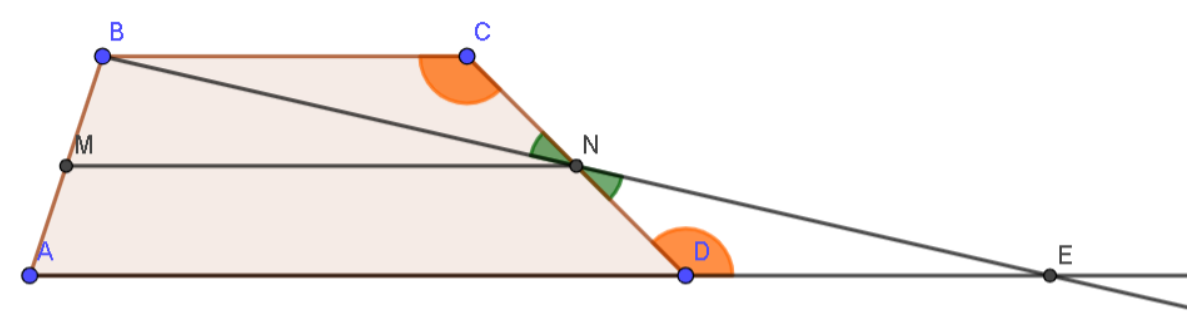

Figura 4.17: Esquema para demonstração da proposição 4.43

Definição 4.44 (Circunferência) Sejam dados um ponto $O$ e uma medida $r$. Denotamos por circunferência de centro $O$ e raio $r$ o conjunto de todos os pontos que estão a uma distância $r>0$ do centro $O$.

Definição 4.45 Seja uma circunferência de centro O. Dados três pontos A, $B$ e $C$ da circunferência, dispostos como na figura abaixo, definimos o ângulo $A \hat{O} B$ como ângulo central e o ângulo $A \hat{C} B$ como ângulo inscrito.

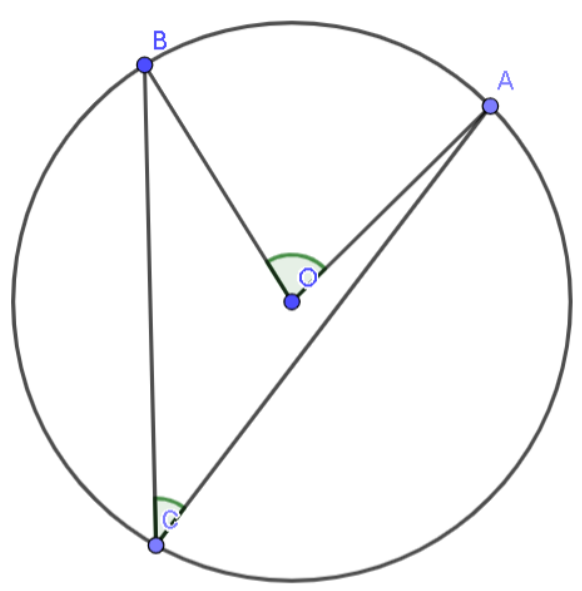

Figura 4.18: Ângulos central e inscrito

Vamos considerar a medida do ângulo central igual a medida do seu arco correspondente. 


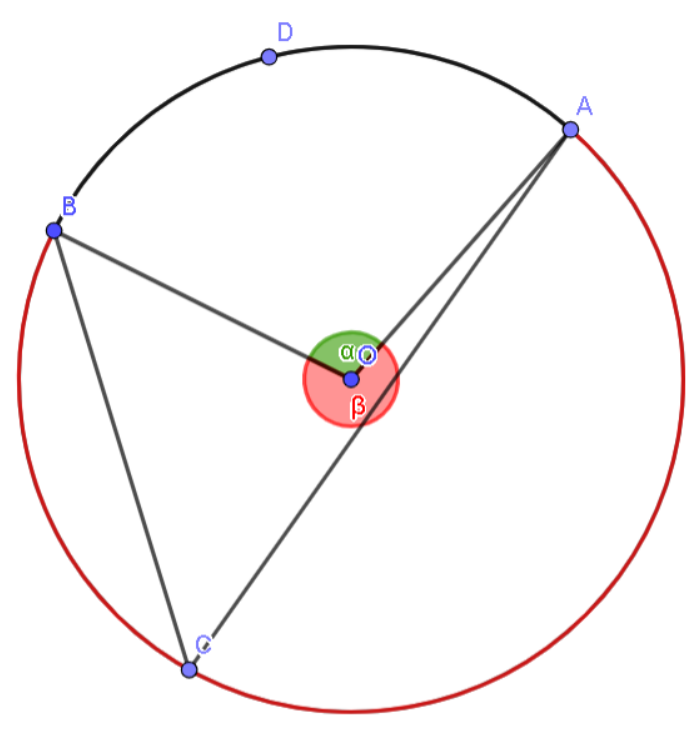

Figura 4.19: Ângulos central e inscrito

Na figura 4.20 temos que o ângulo $\alpha=\widehat{A D B}$ e o ângulo $\beta=\widehat{A C B}$.

Teorema 4.46 Dada uma circnferência de centro $O$ e os ângulos central $A \hat{O} B$ e inscrito $A \hat{C} B$, temos que $A \hat{O} B=\frac{A \hat{C} B}{2}$.

Definição 4.47 Um polígono é dito inscrito em uma circunferência se todos os vértices deste polígono fazem parte da circunferência.

Definição 4.48 Um polígono é circunscrito a uma circunferência se todos os seus lados forem tangentes à esta circunferência.

Definição 4.49 Um polígono é dito convexo se, dados quaisquer segmentos formados por dois pontos distintos do polígono, estes segmentos tem todos os seu pontos, a menos das extremidades, internos ao polígono.

Teorema 4.50 (Teorema do ângulo externo) Dado o triângulo $A B C$, tomemos o ponto $D$, pertencente a semirreta $A B$, de tal forma que $B$ esteja entre $A$ e $D$, todos distintos. Temos que $D \hat{C} B=B \hat{A} C+A \hat{B} C$. Dizemos que o ângulo $D \hat{C} B$ é externo ao triângulo no vértice $C$.

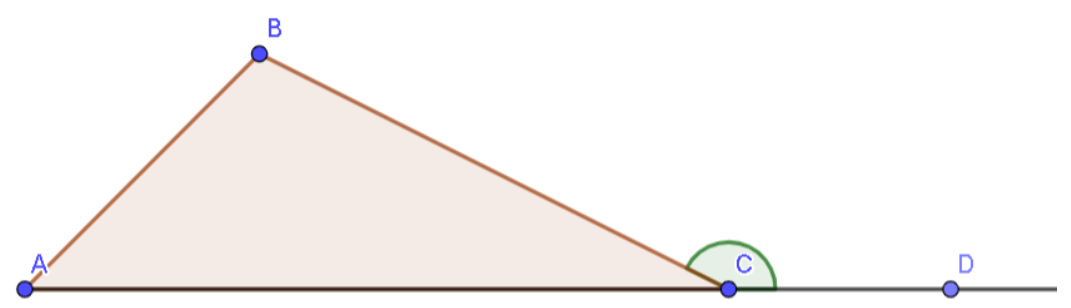

Figura 4.20: Teorema do ângulo externo 
Teorema 4.51 Um quadrilátero convexo é inscritivel em uma circunferência se, e somente se, seus pares de ângulos opostos são suplementares.

Prova. Primeiro vamos demonstrar a ida. Temos então um quadrilátero convexo $\mathrm{ABCD}$ inscrito em uma circunferência. Como $B \hat{A} D=\frac{\overparen{B C D}}{2}, B \hat{C} D=\frac{\widehat{B A D}}{2}$ e $\widehat{B C D}+\widehat{B A D}=360^{\circ}$, temos que $2 B \hat{A} D+2 B \hat{C} D=360^{\circ}$. Ou seja, $B \hat{A} D+B \hat{C} D=180^{\circ}$. Analogamente ocorre para os ângulos $A \hat{B} C$ e $A \hat{D} C$.

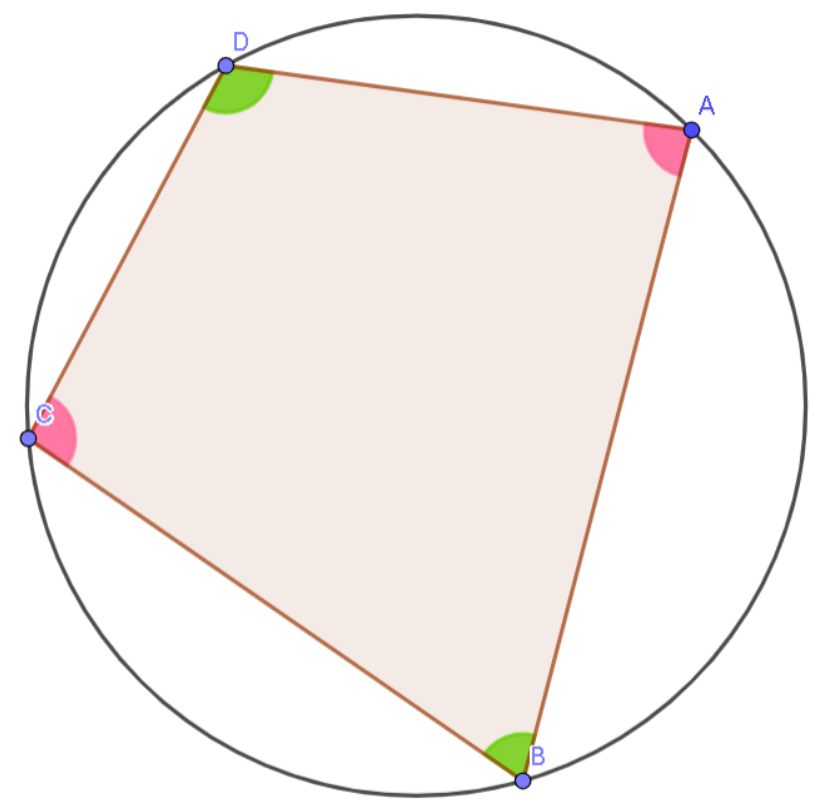

Figura 4.21: Quadrilátero ABCD com ângulos opostos suplementares

Agora iremos demonstrar a recíproca. Sabemos que $B \hat{A} D+B \hat{C} D=$ $A \hat{B} C+A \hat{D} C=180^{\circ}$. Consideremos uma circunferência que passa pelos pontos A, B e C. Quanto ao ponto D, temos duas possibilidades. D pode pertencer ou não à circunferência. Suponhamos que D não pertence a circunferência com D externo a mesma. Seja E o ponto de interseção entre o segmento CD e a circunferência, sendo E um ponto distinto de C. O quadrilátero ABCE é inscrito na circunferência e pelo o que foi provado anteriormente, temos que $A \hat{B} C+A \hat{E} C=180^{\circ}$. Daí $A \hat{D} C=A \hat{E} C$, mas isto é um absurdo, pois pelo teorema do ângulo externo $A \hat{D} C$ deve ser menor que $A \hat{E} C$. Logo D não pode ser exterior à circunferência. De forma semelhante podemos ver que D não pode ser interior à circunferência. Logo $\mathrm{D}$ deve pertencer a circunferência. 


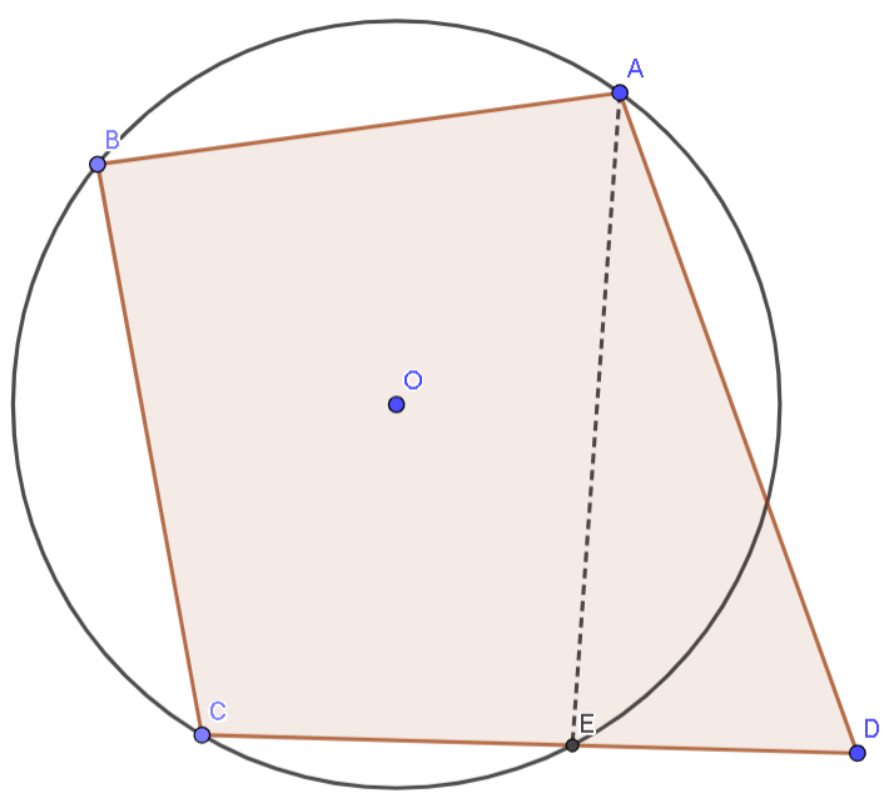

Figura 4.22: Quadriláteros ABCD e ABCE

Teorema 4.52 Seja uma circunferência de centro $O$ e um ponto $C$ externo a esta circunferência. Sejam $r$ e $s$ as duas retas tangentes à circunferência partindo de $B$, tangentes respectivamente nos pontos $A$ e $B$. Os segmentos $A C$ e $B C$ são congruentes e os ângulos $O \hat{A} C$ e $O \hat{B} C$ são retos.

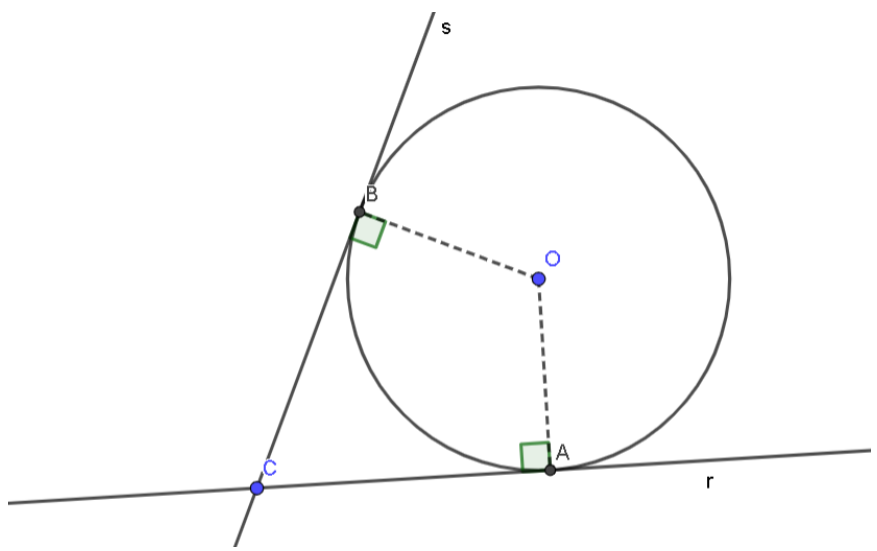

Figura 4.23: Retas tangentes à circunferência

Teorema 4.53 (Desigualdade triangular) Em um triângulo a medida de cada lado é sempre menor que a soma das medidas dos outros dois lados.

Teorema 4.54 Um quadrilátero convexo pode ser circunscrito a uma circunferência se, e somente se, a soma das medidas de dois lados lados opostos for igual a soma das medidas dos outros dois lados opostos. 
Prova. Comecemos pela ida. Seja ABCD um quadrilátero convexo circunscrito a uma circunferência de centro $\mathrm{O}$ e raio r. Denotando os pontos de tangência entre os lados e a circunferência conforme a figura abaixo e utilizando o teorema 4.52 , vemos que $A B+C D=(A E+B E)+(C G+D G)=(A H+B F)+(C F+$ $D H)=(A H+D H)+(B F+C F)=A D+B C$.

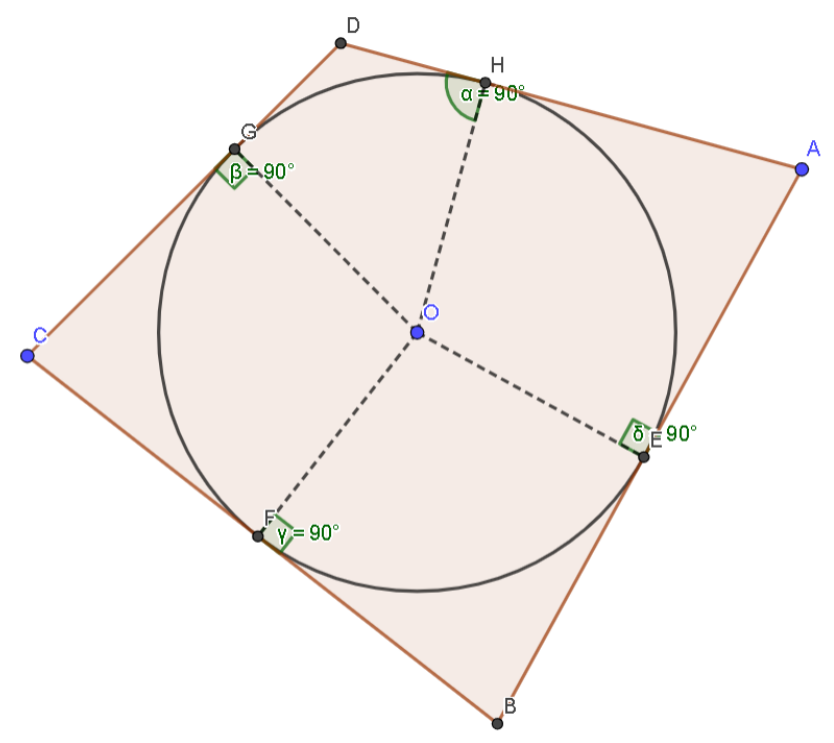

Figura 4.24: Quadrilátero ABCD circunscrito a circunferência

Agora vamos demonstrar a volta. Sabemos que $A B+C D=A D+B C$. Tomemos a circunferência que tangencia os lados $\mathrm{AB}, \mathrm{BC}$ e $\mathrm{CD}$ nos pontos $\mathrm{R}, \mathrm{S}$ e T, respectivamente. Vamos supor que ABCD não seja circunscritível. Tomemos então um ponto D' no segmento CD tal que AD' seja tangente a circunferência no ponto H. Temos que ABCD' é está circunscrito a circunferência em questão. Logo, da parte que já demonstramos, temos que $A D^{\prime}+B C=A B+C D^{\prime}$. Da hipótese, temos que $A B+C D=A D+B C$. Desenvolvendo $A D+B C=$ $A B+C D=A B+\left(C D^{\prime}+D^{\prime} D\right)=\left(A B+C D^{\prime}\right)+D^{\prime} D=\left(A D^{\prime}+B C\right)+D^{\prime} D$. Cancelando $\mathrm{BC}$ nos dois membros da igualdade $A D+B C=\left(A D^{\prime}+B C\right)+D^{\prime} D$ temos $A D=A D^{\prime}+D^{\prime} D$ o que é absurdo devido a desigualdade triangular. Logo ABCD é circunscritível. 


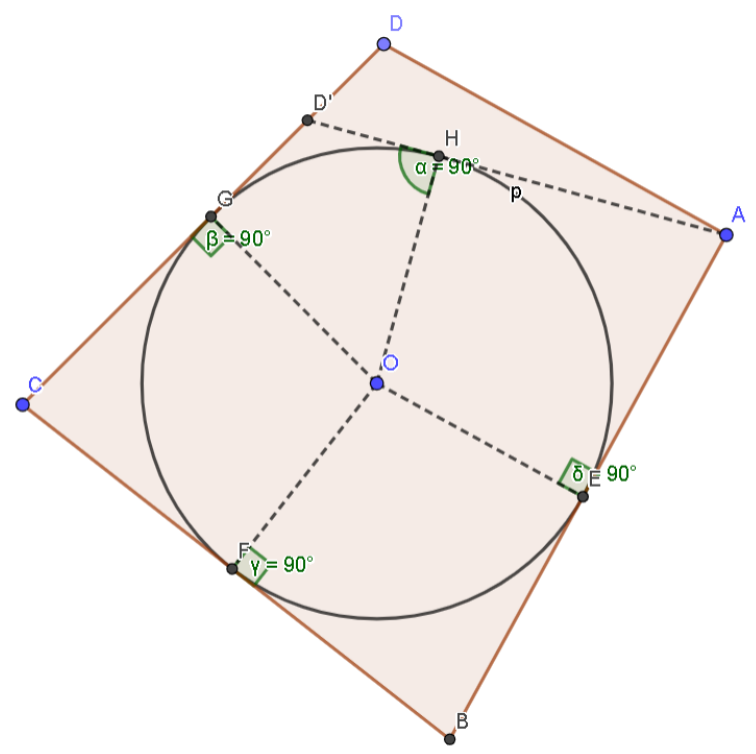

Figura 4.25: Quadriláteros ABCD e ABCD'

\section{5}

\section{Atividade 5}

Na atividade 5 nós falamos de medidas de tendência central e de dispersão de dados. Vamos definir estas medidas e fazer algumas reflexões sobre o significado de cada uma delas.

Seja um conjunto $X=\left\{x_{1}, x_{2}, x_{3}, \ldots, x_{\mathrm{n}}\right\}$ com n observações. Podemos definir:

Definição 4.55 (Média Aritmética) A média aritmética é a razão entre a soma das observção e a quantidade de observações.

$$
\bar{X}=\frac{x_{1}+x_{2}+x_{3}+\ldots+x_{n}}{n} .
$$

Definição 4.56 (Mediana) Ao colocar as n observações em ordem, crescente ou decrescente, temos dois modos de definir a mediana:

a) $n$ impar: O elemento central será o de índice $\frac{n+1}{2}$. Esteelementoseráamediana;

b) n par: O elemento central será a média aritmética dos elementos de índice $\frac{n}{2}$ e $\frac{n}{2}+1$.Estevalorseráamediana.

Definição 4.57 (Moda) A moda é a observação que mais se repete. Um conjunto de observações pode não ter moda, isso vai se dar quando cada observação só aparece uma única vez. Neste caso dizemos que o conjunto é amodal. 
Pode ocorrer também que exista mais de uma moda, formando assim conjuntos bimodais, trimodais e assim por diante.

Essas três definições foram das chamadas medidas de tendência central. Algumas observações importantes podem ser feitas em relação a estas definições. A média aritmética distribui de maneira uniforme o somatório das observações. Já a mediana divide as observações de tal maneira que metade das observações são menores ou iguais a ela e a outra metade com elementos maiores ou iguais a ela.

Definição 4.58 (Variância Amostral) Tomando $n$ observações em uma população, a variância é dada pela razão entre o somatório dos quadrados das diferenças entre as observações e a média e o número de observações.

$V=\frac{\sum_{1 \leq i \leq n}\left(x_{i}-\bar{X}\right)^{2}}{n-1}$

Ao calcular a variância, temos como objetivo observar quão agrupados estão os dados, fazendo com que a média aritmética tenha maior valor estatístico ao ser acompanhada de uma variância pequena, como vimos na atividade sobre os jogadores.

Outra medida de dispersão que vimos na atividade foi o desvio padrão, medida esta que tem relação direta com a variância.

Definição 4.59 (Desvio Padrão) O desvio padrão é a raiz quadrada da variância.

Para fins de comparação, matemáticamente falando, não há diferença entre usar o desvio padrão ou a variância, visto que dados dois valores positivos $x$ e $y \operatorname{com} x>y$, temos que $\sqrt{x}>\sqrt{y}$.

Outra observação importante que deve ser feita sobre o desvio padrão é que ao calculá-lo, voltamos às unidades de medida originais, que foram elevadas ao quadrado ao calcular a variância. 


\section{5 \\ Considerações finais}

Transformar o espaço da sala de aula de Matemática em um espaço que estimule o uso da Língua Portuguesa, em sua forma escrita ou falada, é mais do que possível, é necessário. Vários autores, além dos documentos oficiais, corroboram com essa visão, enxergando os ganhos que a interação entre os conteúdos matemáticos e a língua materna podem gerar ao aluno na obtenção de sua cidadania, alçando o aluno a um papel de protagonista dentro do espaço escolar.

A coleção de atividades proposta pode dar suporte ao docente na busca de uma ressignificação tanto do seu papel no ambiente escolar, quanto da sua prática. Estas atividades podem servir de inspiração para que o docente faça as adaptações necessárias para o uso com seus alunos ou que crie outras atividades com o foco em estimular o uso da escrita e da fala pelo aluno.

A aplicação destas atividades não foi possível por diversos motivos, porém os próximos passos devem consistir em coleta de dados no chão da escola fomentando pesquisas de campo. A partir destes dados pode-se fazer ajustes nas atividades além de criar outras sempre com enfoque no desenvolvimento da fala e da escrita. Este é um campo de pesquisa ainda novo mas com muito a ser desbravado.

É necessário encarar o desafio de tornar o ensino de Matemática mais significativo para os alunos, independente dos conteúdos propostos. Estimular a linguagem escrita e falada se apresenta como um dos caminhos para tornar a Matemática mais natural ao aluno, facilitando a comunicação entre docentes e discentes, derrubando algumas barreiras que costumam ser construídas no ambiente da sala de aula. 


\section{Referências bibliográficas}

ANTON, H., \& RORRES, C. 2012. Álgebra linear com aplicações. 10 $0^{\mathrm{a}}$ edn. Bookman.

BALACHEFF, N. 1987. Processus de Preuve et Situations de Validation. Education Studies in Mathematics, 147-176.

BARBOSA, J. L. M. 2006. Geometria Euclidiana Plana. 10 $0^{a}$ edn. Sociedade Brasileira de Matemática.

BARBOSA, K. C. B., NACARATO, A. M., \& PENHA, P. C. 2008. A escrita nas aulas de matemática revelando crenças e produção de significados pelos alunos. Periódico do Mestrado em Educação da UCDB, Série-Estudos(26), 79-95.

BRASIL. 1998. Parâmetros Currículares Nacionais, Terceiro e Quarto Ciclos do Ensino Fundamental. Brasília, DF: Ministério da Educaçãoe e do Desporto, Secretária de Educação Fundamental.

BRASIL. 2018. Base Nacional Comum Curricular. Brasília, DF: Ministério da Educação.

COURA, F. C. F. 2006. Matemática e língua materna: propostas para uma interação positiva. X Encontro Brasileiro de Estudantes de Pós-Graduação em Educação Matemática.

FERREIRA, N. S. A. 2020. Não só 25 anos de COLE, mas também... Leitura: Teoria Prática, 38(79), 91-101.

FREIRE, P. 1995. Construção de uma nova cultura política. Poder Local, Participação Popular, Construção da Cidadania.

FREIRE, P. 2003. Pedagogia da autonomia - saberes necessários à prática educativa. São Paulo, SP: Paz e Terra.

FREITAS, J. L. M., \& GONÇALVES, M. J. S. V. 2020. Um estudo da oralidade na resolução de problemas de proporcionalidade no Ensino Fundamental. EM TEIA - Revista de Educação Matemática e Tecnológica Iberoamericana, 38(79), 91-101. 
MACHADO, N. J. 1989. Matemática e Língua Materna: Uma aproximação necessária.

MARQUEZ, A. N. G., \& SANTOS, F. G. 2017. O uso de recursos comunicativos nas aulas de Matemática nos anos iniciais do Ensino Fundamental. XII EDUCERE.

MILIES, F. C. P., \& COELHO, S. P. 2006. Números: Uma Introdução à Matemática. $3^{a}$ edn. Editora da Universidade de São Paulo.

NACARATO, A. M. 2012. A comunicação oral nas aulas de Matemática nos anos iniciais do ensino fundamental. Revista Eletrônica de Educação, 6(1), 9-26.

NACARATO, A. M. 2013. A escrita nas aulas de matemática: diversidade de registros e suas potencialidades. Leitura: Teoria Prática, 31(61), 63-79.

PONTE, J. P., \& SOUSA, H. 2010. Uma oportunidade de mudança na Matemática do Ensino Básico. O professor e o programa de Matemática do ensino básico, 11-41. 


\section{A \\ Apêndice - Decomposição em fatores primos}

\section{Parte 1}

Responda as seguintes questões:

a) Explique, com suas palavras, o que é matéria prima:

b) Cite alguns exemplos de objetos ou produtos e suas matérias primas:

c) Você já ouviu falar sobre números primos? Descreva que ideia vem em seu pensamento ao ouvir que um número é primo:

\section{Parte 2}

a) Vamos fazer algumas contas! Vamos tentar escrever os números a seguir como produto da maior quantidade possível de números naturais diferentes de 1. Vamos observar o exemplo abaixo: 
Exemplo: $O$ número 56 pode ser escrito como o produto entre os números 7 e $8(7 \cdot 8=56)$. Agora vamos pensar se é possível fazer o mesmo com os números 7 e 8 . Sabemos que $8=4 \cdot 2$. Logo, podemos fazer $7 \cdot 4 \cdot 2=56$. Como $4=2 \cdot 2$ podemos escrever $7 \cdot 2 \cdot 2 \cdot 2=56$. Antes de fazer o mesmo com outros números, responda: Seria possível continuar o processo dado no exemplo? Justifique sua resposta. Agora faça o mesmo para os números: $12,18,23,30$ e 189.

b) Foi possível realizar o procedimento em todos os números? Se não, descreva qual foi a dificuldade encontrada?

c) Você percebe alguma característica comum aos números encontrados no fim de cada procedimento? Se houver essa característica, explique sobre ela:

d) Dentre os Números Naturais, existem mais números com essa característica? Se houver, apresente alguns desses números: 


\section{Parte 3}

a) Procure o significado da palavra composto e explique o que você entendeu:

b) De acordo com o que foi trabalhado na "Parte 2", podemos dizer que existem números que são compostos por outros? Explique e cite alguns exemplos:

c) Explique como um número pode ser considerado matéria prima para compor novos números:

d) Faça a sua definição de número primo e de número composto. Existe algum Número Natural que não é primo e nem composto? Explique: 


\section{B \\ Apêndice - Perpendicularidade entre o raio e a reta tangente a um círculo}

\section{Parte 1}

Observe a figura abaixo e meça, com uma régua, a distância do ponto $A$ até a reta $r$ nas duas situações. Ao medir, trace o segmento de reta que você usou para aferir a medida.
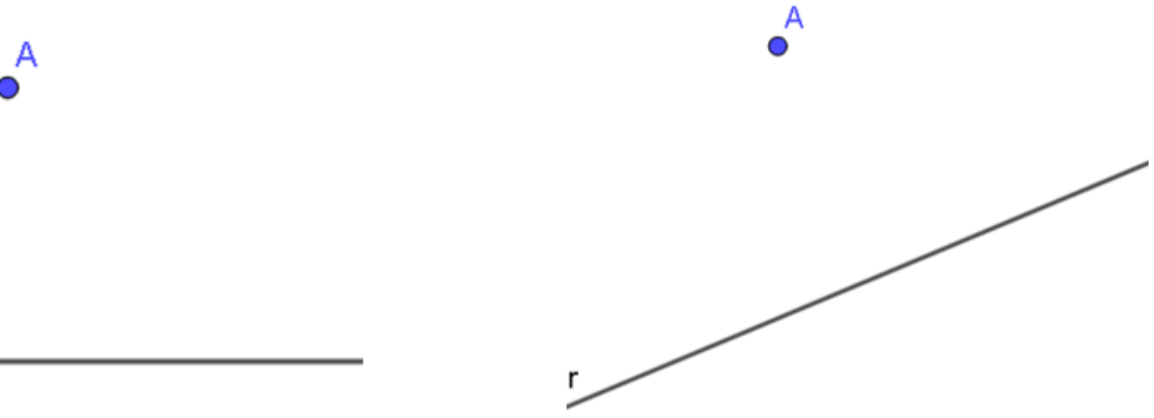

Escreva o processo que você utilizou para aferir as medidas nos dois casos:

\section{Parte 2}

Observe a figura, em que está representado um círculo de centro $\mathrm{O}$ e uma reta tangente a este círculo no ponto $B$, e responda as seguintes questões:

a) Descreva em que situação uma reta é tangente a um círculo:

b) Qual dos pontos $A, B$ ou C, da reta, está mais próximo do centro O? Explique sua resposta: 
Apêndice B. Apêndice - Perpendicularidade entre o raio e a reta tangente a um círculo

c) Existe algum ponto na reta, diferente dos pontos já marcados, que seja o mais próximo do centro $\mathrm{O}$ ? Justifique:

d) Trace o segmento entre o centro $\mathrm{O}$ e o ponto da reta que é o mais próximo deste centro. Qual o ângulo entre esse segmento e a reta?

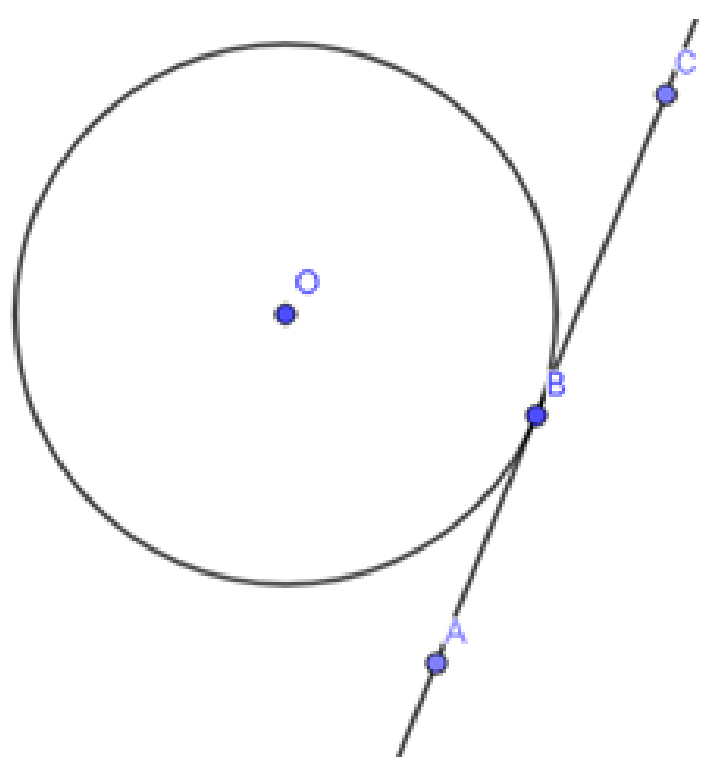


C

\section{Apêndice - Criando um problema a partir de um sistema de} equações lineares

Observe o sistema de equações abaixo e faça o que é proposto a seguir:

$\left\{\begin{array}{c}20 x-10 y=100 \\ x+y=80\end{array}\right.$

a) Crie um problema de tal forma que a solução possa ser modelada pelo sistema de equações dado:

b) Qual o significado das variáveis x e y no problema que você criou?

c) Como você resolveria este sistema? Resolva-o e explique a escolha do método que você utilizou: 
Apêndice C. Apêndice - Criando um problema a partir de um sistema de equações lineares

d) Represente a situação apresentada no plano cartesiano, explicando o que a posição relativa entre as retas representa em relação à resolução do sistema de equações: 
D

\section{Apêndice - Definições e propriedades de algumas figuras geométricas}

Observe a figura abaixo, em que estão representados um quadrado e um círculo, tangentes no ponto $\mathrm{C}$. $\mathrm{O}$ círculo é tangente à reta $\mathrm{r}$ no ponto $\mathrm{B}$ e esta reta contém o lado DE do quadrado. Com base nessas informações responda:

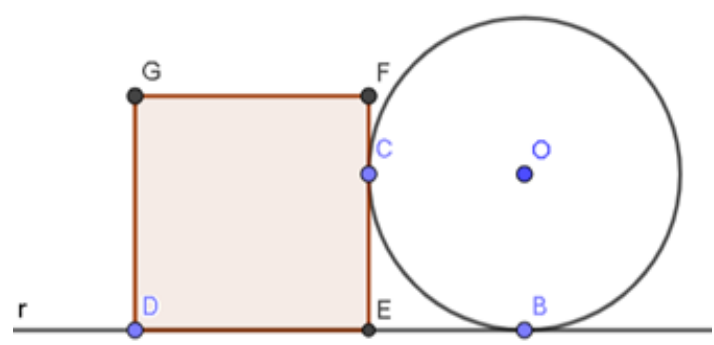

a) Descreva o que caracteriza um quadrado:

b) É possível formar outro quadrado com os pontos denotados na figura? Justifique:

c) Quantos triângulos retângulos você consegue formar com os pontos denotados na figura? Justifique: 
Apêndice D. Apêndice - Definições e propriedades de algumas figuras geométricas

d) "Os segmentos DF e EO são paralelos." Esta sentença é verdadeira ou falsa? Argumente:

e) Escreva a definição de trapézio e verifique se é possível construir um trapézio com os pontos denotados na figura. 
E

\section{Apêndice - Medidas de tendência central e dispersão}

Imagine que você é diretora ou diretor de um grande clube de futebol. Seu clube está precisando de um atacante e foram oferecidos três atletas. Você deve tomar a decisão de contratar um destes jogadores, baseando-se em algumas estatíticas.

a) A tabela abaixo mostra a média de gols dos jogadores, nos últimos dez jogos em que eles jogaram:

Tabela E.1: Média de gols

\begin{tabular}{|c|c|}
\hline Jogador & Média de gols por jogo \\
\hline $\mathrm{A}$ & 1 \\
\hline $\mathrm{B}$ & 0,8 \\
\hline $\mathrm{C}$ & 1,2 \\
\hline
\end{tabular}

Estes dados são suficientes para você tomar uma decisão? Se sim, qual foi sua escolha? Se não, quais dados a mais você precisa?

b) Após sua equipe fazer uma pesquisa, foram encontrados mais dados sobre estes jogadores, uma tabela contendo o número de gols nos últimos 10 jogos em que eles jogaram:

Tabela E.2: Distribuição de gols por jogo nos últimos 10 jogos

\begin{tabular}{|c|c|c|c|c|c|c|c|c|c|c|}
\hline Jogador & Jogo 1 & Jogo 2 & Jogo 3 & Jogo 4 & Jogo 5 & Jogo 6 & Jogo 7 & Jogo 8 & Jogo 9 & Jogo 10 \\
\hline A & 1 & 0 & 2 & 0 & 3 & 0 & 0 & 2 & 2 & 0 \\
\hline B & 1 & 1 & 0 & 1 & 0 & 1 & 1 & 1 & 1 & 1 \\
\hline C & 4 & 2 & 0 & 0 & 0 & 0 & 2 & 2 & 2 & 0 \\
\hline
\end{tabular}

Com estes novos dados em mãos, se você já tomou uma decisão você a mudaria? Se não havia tomado decisão, com estes novos dados você já consegue se decidir? Explique. 
c) Agora você deve justificar sua escolha para os investidores do clube. Prepare um gráfico de barras com os dados da "Tabela 3.7", calcule a variância, o desvio padrão e apresente suas conclusões. 